\title{
Commercial alkaline earth boroaluminosilicate glasses for sealing solid oxide cell stacks Part II: Characterization of devitrification and glass-ceramic phase assemblages
}

\author{
Agersted, Karsten; Balic-Zunic, T.
}

Published in:

International Journal of Applied Ceramic Technology

Link to article, DOI:

10.1111/ijac.12834

Publication date:

2018

Document Version

Peer reviewed version

Link back to DTU Orbit

Citation (APA):

Agersted, K., \& Balic-Zunic, T. (2018). Commercial alkaline earth boroaluminosilicate glasses for sealing solid oxide cell stacks Part II: Characterization of devitrification and glass-ceramic phase assemblages. International Journal of Applied Ceramic Technology, 15(2), 267-285. https://doi.org/10.1111/ijac.12834

\section{General rights}

Copyright and moral rights for the publications made accessible in the public portal are retained by the authors and/or other copyright owners and it is a condition of accessing publications that users recognise and abide by the legal requirements associated with these rights.

- Users may download and print one copy of any publication from the public portal for the purpose of private study or research.

- You may not further distribute the material or use it for any profit-making activity or commercial gain

- You may freely distribute the URL identifying the publication in the public portal 
DR KARSTEN AGERSTED (Orcid ID : 0000-0002-5270-7441)

Article type : Special Issue Article

Commercial alkaline earth boroaluminosilicate glasses for sealing solid oxide cell stacks

Part II: Characterization of devitrification and glass-ceramic phase assemblages

Karsten AGERSTED, Technical University of Denmark, Dept. of Energy conversion and storage,

Denmark (kagn@dtu.dk corresponding author)

T. Balic-Zunic, Copenhagen University, Museum for natural history, Denmark

\section{Abstract}

The devitrification process and formation of crystalline phases from commercial alkaline earth boroaluminosilicate glasses containing 48-61 mol\% $\mathrm{SiO}_{2}$, $18-28 \mathrm{~mol} \% \mathrm{CaO}, 1-7 \mathrm{~mol} \% \mathrm{MgO}, 7-10$ mol\% $\mathrm{Al}_{2} \mathrm{O}_{3}, 1-11$ mol\% $\mathrm{B}_{2} \mathrm{O}_{3}$ plus minor amounts of $\mathrm{Na}_{2} \mathrm{O}, \mathrm{K}_{2} \mathrm{O}, \mathrm{FeO}$ and $\mathrm{TiO}_{2}$ were quantified through analysis of phase assemblages as function of heat treatments above the glass transition temperatures using the electron microprobe and powder X-ray diffraction. Treatments at $800{ }^{\circ} \mathrm{C}$ and $850^{\circ} \mathrm{C}$ lasted up to 6 weeks.

Results indicate that devitrification was strongly activated through presence of heterogeneous nucleation, and that the growth mechanism gradually changed from three-dimensional growth at the onset of devitrification towards one-dimensional growth in later stages, when heterogeneous nucleation was absent or less dominating.

This article has been accepted for publication and undergone full peer review but has not been through the copyediting, typesetting, pagination and proofreading process, which may lead to differences between this version and the Version of Record. Please cite this article as doi: $10.1111 /$ ijac. 12832

This article is protected by copyright. All rights reserved. 
Most glasses developed entangled and fibrous microstructures with little or no residual glass phase, which are adequate for rigid sealants, and only one of the laboratory analogue glasses, MCAS, developed microstructures with both more equiaxed grains and a considerable amount of residual glass phase, which may be adequate for more compliant and self-healing sealants as often required in SOC-applications.

Even though the glasses lie within a relatively narrow compositional range, resulting phase assemblages differed significantly. Anorthite (plagioclase) developed as the main crystalline phase in all samples together with pyroxene (or pyroxenoide) and cristobalite. Calciummagnesium-silicate pyroxene (diopside) was in a large part replaced by the calcium-silicate pyroxenoid (wollastonite) in the samples where the mol-proportion MgO:CaO was 1:5 or lower. In samples with a very low $\mathrm{MgO}$ proportion and consequently a high $\mathrm{CaO}$ proportion, calcium metaborate and calcium aluminum borosilicate (okayamalite) crystallized among the main phases and these glasses crystallized completely within the period of heat treatment. Although cristobalite is metastable at the annealing temperatures, both $\alpha$ and $\beta$ forms were rapidly formed in most of the samples, likely due to kinetic reasons. The presence of the latter is explained by the stabilization effect of Al and B substitution for Si compensated by Ca stuffing in the structure. The stuffed cristobalite transformed with time to quartz (at $800^{\circ} \mathrm{C}$ ) or quartz plus tridymite (at $850^{\circ} \mathrm{C}$ ). Boron was incorporated in the first crystallizing phases, especially diopside, substituting for $\mathrm{Al}$ and $\mathrm{Si}$, but the so established substitution partly disappeared with time during the heat treatment.

This article is protected by copyright. All rights reserved. 


\section{Introduction}

Glass ceramic sealants for solid oxide cell (SOC) stacks are primarily characterized for their sealing and thermomechanical behavior, in specific settings or environments in terms of neighbor components and sealing profile, being the most relevant factors if a limited number of sealants are to be evaluated. If more candidates are at hand, a different approach may be taken, as in this work, where a comparison of sealing properties and development of phase assemblages in a set of commercially available alkaline earth boroaluminosilicate glasses was conducted to become independent of influence from any neighbor components and make results generally applicable. These glasses are better known for their durability and low thermal expansion, but have shown to attain sufficiently good sealing properties in the temperature range of interest for solid oxide cell (SOC) sealants as well as satisfactory performance through repeated thermal cycling ${ }^{1,2}$. Glasses are containing 48-61 mol\% $\mathrm{SiO}_{2}, 18-28 \mathrm{~mol} \% \mathrm{CaO}$, 1-7 mol\% $\mathrm{MgO}, 7-10 \mathrm{~mol} \% \mathrm{Al}_{2} \mathrm{O}_{3}, 1-11 \mathrm{~mol} \%$ $\mathrm{B}_{2} \mathrm{O}_{3}$ plus minor amounts of $\mathrm{Na}_{2} \mathrm{O}, \mathrm{K}_{2} \mathrm{O}, \mathrm{FeO}$ and $\mathrm{TiO}_{2}$ and may be seen as an alternative to more expensive commercial glasses in which thermomechanical match towards sealing counterparts and medium to high coefficients of thermal expansion (CTE), e.g. in the range $10-1310^{-6} \mathrm{~K}^{-1}$ as experienced in SOC stacks, have been tailored through higher contents of alkaline or alkaline earth metals, e.g. barium or strontium, or other metal ions with relatively high ionic radii.

Prior to the present work it has been observed that smaller variations in the composition of the commercial glasses sold under the same label as well as variations in the processing of the glasses, e.g. milling, introduced marked differences in the sealing behavior as well as the thermomechanical properties of the glass ceramics. To investigate how different processing routes; hyper-quenching, as used in mass production of fibrous glasses and quenching, as typically used in production of smaller batches, laboratory analogues of the commercial glasses were also included in the study. Hence, the scope of the work was to characterize how the devitrification processes and the phase assemblages developed due to influences from variations

This article is protected by copyright. All rights reserved. 
in nucleation mechanism and overall composition. Particular interest has been on possible influences from the boron content in the glasses, and establishing reliable procedures for quantification of the boron-contents in the various phases of the assemblies have been prioritized.

Crystallization from a glass has routinely and successfully been characterized by DTA/DSC techniques following the findings of Matusita et al. ${ }^{3,4}$ although their procedure was developed to describe simpler systems than often cited in literature and assumes that the thermal response can be ascribed to one dominant devitrification process. Despite fundamental shortcomings in complex systems like the alkaline earth boroaluminosilicate the method has been used to illustrate differences in the crystallization behavior between non-milled fiber materials and milled materials. Viscosities of the glasses were not measured in particular, e.g. by hot stage microscopy ${ }^{5}$, but modelled according to a generalized procedure developed for industrial glasses ${ }^{6}$ based on the statistical behavior of the individual components of the glasses. The model predicts viscosity with an error of $\pm 12{ }^{\circ} \mathrm{C}$ within the compositional limits specified and produces parameters $\left(A, B, T_{0}\right)$ for calculation of viscosities according to the Vogel-Fulcher-Tammann (VFT) equation ${ }^{7}$ above $T_{\mathrm{g}}$ for the glasses:

$\log (\eta)=A+B /\left(T-T_{0}\right)(P a * s)$

(1)

\section{Experimental}

The glasses f11 and f30 listed in Table 1 designate commercially available glass fiber materials (f), which experienced hyper-quenching during fiber spinning. They have been cut into shorter fibers and heated to $500{ }^{\circ} \mathrm{C}$ in air for 2 hours to remove organic species. Crushed fiber versions, with

This article is protected by copyright. All rights reserved. 
the prefix "cf", were produced from grinding such fibers in a ball mill and subsequently in a planetary mill equipped with zirconia milling media. MCAS and c30b were both made from analytical grade Me-oxides and carbonates mixed in a ball mill, heated at $2{ }^{\circ} \mathrm{C} / \mathrm{min}$ and held at $1400{ }^{\circ} \mathrm{C}$ for 4 hours before cooling to room temperature at $2^{\circ} \mathrm{C} / \mathrm{min}$. Subsequently, a second batch of raw materials was added to the crucible and the melting procedure was repeated two more times, hence processing one third of the raw materials each time. The glass was then heated again to $750^{\circ} \mathrm{C}$, quenched in water and thereafter ground to powder. Glass $\mathrm{P}$, a commercial low-Boron glass hyper-quenched as pearls, was sieved and only pearls passing a 45 $\mu \mathrm{m}$ mesh were used for the experiments.

The ground glass materials (MCAS, cf11, cf30 and c30b) having average grain sizes below $10 \mu \mathrm{m}$ and the glass pearls (glass $\mathrm{P}$ ) were uniaxially pressed at $40 \mathrm{MPa}$ into rectangular pellets of welldefined length $(50 \mathrm{~mm})$, height $(5 \mathrm{~mm})$ and width $(7-10 \mathrm{~mm})$, which weighted between $3.3 \mathrm{~g}$ and $5 \mathrm{~g}$. An organic binder solution was added in small amounts to facilitate handling of the pellets. To obtain coherency of samples from glass $\mathrm{P}$, this material was subjected to a pressure less than $20 \mathrm{MPa}$ equivalent to the minimum reading of the press. Unsuccessful attempts were made to press the fibers of $\mathrm{f} 11$ into pellets and instead fibers were stacked and annealed in the asreceived shape: $\sim 6 \mathrm{~mm}$ long fibers with a diameter of $\sim 6.5 \mu \mathrm{m}$. All samples rested on gold foil during the annealing.

The samples were heated with a heating rate of $100^{\circ} \mathrm{C} / \mathrm{h}$ and held at the annealing temperature for $4 \mathrm{~h}, 24 \mathrm{~h}, 168 \mathrm{~h}, 336 \mathrm{~h}$ or $1008 \mathrm{~h}$ respectively, and hereafter quickly removed from the furnace and cooled by exposure to room temperature. Reference samples of each glass were removed from the furnace shortly after reaching the desired temperature, and these samples have been assigned an arbitrary value of $1 \mathrm{~h}$ in the following, to mark the starting point. Both the temperature uniformity inside the furnace and the long-term drift varied in the order of a few

This article is protected by copyright. All rights reserved. 
degrees, which is regarded as negligible for the desired temperature accuracy. The furnace was opened several times for removal of samples, but the short-term drop in temperature of about $50^{\circ} \mathrm{C}$ experienced by samples kept in the furnace for longer times is considered not to influence the results.

Analytical methods

Pellets were cut, mounted in epoxy, polished and carbon-coated for evaluation of microstructure and chemical composition in an electron microprobe (WDS in JEOL Superprobe JXA-8200) at accelerating voltage of $8 \mathrm{kV}(10 \mathrm{kV}$ when measuring $\mathrm{Fe}, \mathrm{Ti}$ and $\mathrm{B})$ and a current of $6 \mathrm{nA}$. Working distance (WD) was $11 \mathrm{~mm}$ and count intervals generally of $10 \mathrm{~s}$ on the peak and $5 \mathrm{~s}$ on the background on each side of the peak ( $20 \mathrm{~s}$ and $10 \mathrm{~s}$, respectively, for boron) with a spot size of 2 $\mu \mathrm{m}$. Table 1 lists the standards used for each element. The first attempts using danburite as the boron standard resulted in a poor match to the values of boron contents determined by wetchemical analysis of glasses. A reason may be that the coordination environment of boron in danburite significantly differs from the boron coordination in the glass ${ }^{8}$. Therefore a sample of the MCAS glass was chosen as a standard for boron, with the quantity of $\mathrm{B}_{2} \mathrm{O}_{3}$ obtained from the wet-chemical analysis. Parts of the heat treated samples were crushed to a fine powder in an agate mortar for XRD measurements with Cu Ka-radiation in a Bruker-AXS D8 diffractometer equipped with a primary Ge(111) mono-chromator and a LynxEye fast Si-strip position sensitive detector covering $3.3^{\circ}$. Measurements were performed in reflection mode within a $2 \theta$ range of $5^{\circ}$ to $90^{\circ}$, with step size of $0.02^{\circ}$ and 4 s step time.

DSC analysis in a Netzsch DSC 404 C were done by heating of the powdered glass samples $\left(d_{50}<\right.$ $10 \mu \mathrm{m})$ in argon at four different heating rates; $1,5,10,40^{\circ} \mathrm{C} / \mathrm{min}$ until $1300^{\circ} \mathrm{C}$. The range of heating rates include the relative low heating rates, $1-2^{\circ} \mathrm{C} / \mathrm{min}$, used in SOC stack sealing and initialization. Baselines were established for each heating rate and subtracted from raw data. Sample size was held constant at 25-30 mg.

This article is protected by copyright. All rights reserved. 
For XRD at elevated temperatures a MRI BASIC high temperature stage (max. temp. $1500^{\circ} \mathrm{C}$, sample holder Pt20\%Rh) was used at a $2 \theta$ range from $5^{\circ}$ to $100^{\circ}$, step size of $0.0099^{\circ}$, step time of $1 \mathrm{~s}$ and a divergence slit with $\mathrm{v}=6.00$. Powders were suspended in ethanol, applied onto the sample holder and dried prior to analysis.

Preliminary phase identification was performed in EVA software package (Bruker AXS product). Quantitative phase analysis (QPA) using the Rietveld method ${ }^{9,10}$ was done through the software TOPAS vers. 4.1 from Bruker AXS. Crystal lattice parameters for the detected phases and sources for the crystal structure data are listed in Table 2. During Rietveld refinement only the crystal lattice parameters, scale factors and crystallite sizes were varied for crystalline phases, atomic parameters were kept constant. Fundamental profile method was used and a $\mathrm{CeO}_{2}$ sample of a known average crystallite size $(590 \mathrm{~nm})$ used as external standard. Due to the large number of samples, the amount of the residual glass (amorphous component) was not determined by the relatively accurate addition method, but by a simpler one which did not require the additional sample preparation and doubling of the analyses. It was recognized that the amorphous signal of the borosilicate glass can be modelled by a pseudo-quartz structural model, which releases the lattice parameters and crystallite size in crystalline data of quartz and adjusting the atomic site occupancies to achieve the appropriate glass densities, cf. Figure 1. The "crystal lattice parameters" thereby obtained deviated from the real quartz values and the nominal crystallite size, which determines the width of the diffraction maxima, was of an extremely low value (0.8$0.9 \mathrm{~nm})$. The diffraction characteristics of each glass were obtained by this procedure on the start samples heat-treated for one hour. They proved to be either pure or over $90 \%$ glasses. The modelled structural parameters for glasses were subsequently used for quantitative estimations during Rietveld refinement of other samples, only adjusting the scale factor for the glass function. To check the accuracy of the method, the samples of glasses cf11 and c30b treated for four weeks at $800^{\circ} \mathrm{C}$ were also investigated by the combination of Rietveld refinement and the addition method ${ }^{11}$ for which exact equations exist and where the amorphous signal is modelled This article is protected by copyright. All rights reserved. 
as a part of the background. The additive, quartz, was chosen in order not to change the X-ray absorption in the sample significantly. The amounts of glass determined by the combination of Rietveld refinement and the addition method were $18.4 \mathrm{wt} \%$ and $0 \mathrm{wt} \%$ to be compared to the amounts of glass obtained by the presently applied method, which were $19.3 \mathrm{wt} \%$ and no glass, respectively. The results in other samples reported here were additionally checked by recalculating the results of the Rietveld refinements in summary wt\% of oxides and comparing with the known starting composition of the glasses. The specific response of the vitreous phase in the applied method may change with glass composition, e.g. boron enrichment, as well as with phase separation, but the relatively good correlation between results with and without standard addition has led to an acceptance of the applicability of the method. Mass balances showed nonsystematic overestimations of silica and underestimation of $\mathrm{B}_{2} \mathrm{O}_{3}$, but as these were mainly found in glasses with phase separation (MCAS, $f 11, \mathrm{cf} 11$ ) it has been ascribed more to the uncertainty of the average composition of the glass phases measured by EMPA. Randomly distributed discrepancies in wt\% of other oxides amounted to few percent, relatively, which is at a similar level as the accuracy of the glass content estimations that lies within few wt\%,

\section{Results}

Figure 2 depicts the result from modelling ${ }^{6}$ the glass viscosity and it is seen that pristine glasses do not differ very much, except for the laboratory-analogue, c30b, which may be expected to appear more viscous than its commercial model, cf30, and maybe even show faster nucleation and crystallization properties. The modeling also illustrates a marked increase of the fragility of the vitreous phase as function of the compositional changes induced by crystallization on aging.

This article is protected by copyright. All rights reserved. 
Figures 3-5 show a set of results; the development of phase assemblages with time at fixed temperatures, concentration of oxides (EMPA) in the residual glass phases and selected examples of the microstructures for the glass f11. Subsequent figures 6-15 follow this template and cover similar results for the lot of glass ceramics and annealing conditions used in the present study. The volume fraction of the phase assemblages have been shown in log-log scaling, and in the cases where linear trend lines could be drawn, the slope of these trends have been listed in Table 3 to illustrate the difference between crystallization processes that are hindered, slope $<1$, and processes that are not, slope $=1$. Slopes significantly higher than unity likely indicate conditions of eutectic crystallization or supersaturation. The EMPA-analysis on residual glass phases showed that in general, concentrations of magnesium, aluminum, silicon, and sodium dropped after the onset of crystallization, whereas concentrations of calcium and boron rose cf. Figures 4, 7, 10, 13, which also complies well with another general observation that crystallization of nominally boron-free phases were kinetically favored and that the glass transition temperatures of the residual glass phases, $\mathrm{Tg}$, generally decreased on aging.

Selected results from characterization of the devitrification processes ${ }^{3,4}$ have been listed in Table 4. The Avrami parameter, $n$, has been calculated as the linear slopes from so-called Ozawa-plots ${ }^{3}$ of $\ln [-\ln (1-x)]$ versus $\ln (\alpha)$, in which " $x$ " denotes the degree of reaction (crystallization) at selected temperatures (T) evaluated from the areas of the DSC-peak obtained at various heating rates " $\alpha$ ". $G(T)$ denotes a crystallization function, dependent on the mechanism and constant at constant temperature:

$\ln [-\ln \{1-x(T)\}]=G(T)-n \ln (\alpha)$

The Avrami parameter assumes values close to unity (1) for the glasses MCAS, cf30 and c30b, which corresponds well to expectations of surface nucleation dominating the devitrification processes. In contrast, the Avrami parameter for the milled fibers, cf11, is far from being constant

This article is protected by copyright. All rights reserved. 
and seems to drop from higher numbers at lower temperatures towards unity as temperature increases and thereby following the trends of the Avrami parameters for the non-milled and quenched samples, f30, f11, Glass P.

The influence from temperature on the devitrification process can be seen from Figures 3 and 6 where the temperature increase of $50 \stackrel{\circ}{ } \mathrm{C}$ reduced the time for onset of the devitrification from approximately $100 \mathrm{~h}$ to about $6 \mathrm{~h}$ for $\mathrm{f} 11$ and from about $10 \mathrm{~h}$ to $1 \mathrm{~h}$ for cf 11 . The development of phase assemblages seemed in both cases to be relatively unaffected by the temperature difference and the distribution of elements among the main phases after $1000 \mathrm{~h}$ ageing was relatively consistent. The figures also illustrates that introducing sites for heterogeneous nucleation by crushing the fibers reduced the time for onset of devitrification by approximately an order of magnitude as well as promoted the transition from cristobalite into quartz. A possible effect of homogeneous nucleation may be observed in comparing the phase assemblages in cf30 and c30b, cf. Figure 9, where the different crystalline borate phases may reflect different nucleation patterns. A similar comparison between MCAS and cf11 points towards a faster onset of devitrification of the slowly cooled sample, and to differences in the microstructure of the glass ceramics that appears more homogeneous for the quenched and milled sample. A similar trend is also observed between samples of c30b and cf30.

Anorthite (plagioclase) crystallized among the first appearing phases in all glasses and is also the main phase in all samples having a composition, except in glass $\mathrm{P}$, very close anorthite with only 5-10 mol\% Na. Glass P contained more than twice the alkali content to calcium compared to the other glasses and the plagioclase, which formed therein had a larger unit cell, $1345 \AA^{3}$ compared to $1330-1335 \AA^{3}$ in the others, so it is expected that anorthite in glass $\mathrm{P}$ incorporated more $\mathrm{Na}$ than in other samples. Rietveld refinement was tried with various structural data from the plagioclase family. The best $\mathrm{R}$ factor was obtained with the data of andesine with $37 \mathrm{~mol} \%$ anorthite ${ }^{12}$ and the plagioclase in glass $\mathrm{P}$ is probably more albitic than anorthitic. For anorthite in This article is protected by copyright. All rights reserved. 
other samples, the crystal structure data of plagioclases ${ }^{13}$ with 96 mol\% anorthite (cf30, f11) and 89 mol\% anorthite (MCAS, cf11, c30b) were used in Rietveld refinements. XRD observations showed a slow growth of the anorthite (plagioclase) unit cell volume during annealing. The crystallite size of anorthite, except in glass $P$, grew from the starting average size (XRD) of $100 \mathrm{~nm}$ to about $200 \mathrm{~nm}$ in six weeks. The average crystallite size of plagioclase in glass P was significantly lower and remained around $50 \mathrm{~nm}$ even after the six weeks.

In both $\mathrm{f} 11$ and to some extent also in the $\mathrm{cf} 11$, initial plagioclases showed a high silica-content and cation to oxygen ratios around 4.7 to 8 , cf. Table 5 . The composition was relatively consistent in all samples, but was outside the range of both supersilicic anorthite with vacancies in Ca sites (up to $11 \%$ vacancies $^{14}$ ) and stuffed cristobalite (below $10 \%$ substitution/stuffing ${ }^{15}$ ) and falling approximately half-ways between them. Additionally to a general boron and magnesium depletion on aging, plagioclase was observed by both XRD and EMPA to partly re-crystallize, and the starting non-stoichiometric compositions were gradually replaced by stoichiometric phases, cf. Table 5. This was not seen similarly in the more calcium-rich cf30 and c30b glasses. In MCASglass, that has almost the same ( $\mathrm{Mg}, \mathrm{Ca})$-proportion as $\mathrm{f11}$ and $\mathrm{ff} 11$, the anorthite-cristobalite "solid solution" was also transient and seemed to be coexisting with pure and boron-free anorthite.

Diopside is the second most abundant phase, except in cf30, $\mathrm{c} 30 \mathrm{~b}$ and in glass $\mathrm{P}$ where it was partly replaced by wollastonite. Diopside also crystallized among the first appearing phases and showed compositional changes with time, cf. Table 6. In all samples, the diopside, which crystallized first, had a larger Al and B substitution for Si (EMPA), and the proportions of Al and especially B decreased with annealing. Diopside was also a sink for amounts of Fe and Ti present in glasses, which together with Al partly substituted $\mathrm{Mg}$ in all samples (EMPA) ${ }^{16}$. The changes of the crystal lattice parameters were small, showing a general increase of the unit cell dimensions with time. This was due to the expansion of the a- and b-lattice periods, whereas the c-period contracted slightly, which is in accordance with contraction of pyroxene chains, which run in this

This article is protected by copyright. All rights reserved. 
direction, caused by diminishing amounts of Al and B substituting for Si. The crystallite sizes of diopside were typically larger than those of anorthite/plagioclase showing average sizes around 200-300 nm. The crystal structure data used in Rietveld refinement of diopside were those for the aluminian diopside ${ }^{17}$ but with the atomic site occupancies derived for each case from the corresponding EMPA results. The Si- and Mg-substitutions diminished with time, cf. Table 6, but diopside still kept substitution of trivalent cations in both T and M1 sites at $1008 \mathrm{~h}$ and can be classified as aluminous diopside.

Wollastonite appeared prior to diopside in samples $\mathrm{c} 30 \mathrm{~b}$ and $\mathrm{cf} 30$, which had lower magnesium to calcium ratios than MCAS and f11, and simultaneously with diopside in glass-P, which had significantly lower alumina and borate and higher silica concentrations. Wollastonite showed much smaller, if any, substitution of $\mathrm{Al}$ and $\mathrm{B}$ for $\mathrm{Si}$ and was always very close to stoichiometric $\mathrm{CaSiO}_{3}$ (EMPA). Like anorthite and diopside, wollastonite showed a growth of the unit cell volume with annealing (XRD). The average crystallite size of wollastonite matched that of diopside except in glass $\mathrm{P}$, where it was significantly smaller and also showed a smaller unit cell volume than wollastonite in cf30, cf. Table 2. The crystal structure data for wollastonite used in Rietveld refinement were those of the most common $1 \mathrm{~A}$ polytype ${ }^{18}$. Wollastonite in the shape of small dendritic crystals of an average size below $100 \mathrm{~nm}$ made about $1 / 3$ of the volume in glass $P$, whereas diopside formed mostly as isolated crystals of larger sizes around $1 \mu \mathrm{m}$. It is also interesting to note that even though wollastonite was readily formed in c30b, it seemed to be resorbed on further aging, which was not happening as apparent in cf30.

Cristobalite was present in all samples and represented the first crystallizing form of silica, which typically appeared a little later than anorthite and diopside/wollastonite on annealing, except in glass $\mathrm{P}$ where it was present at $\sim 2$ vol\% from the very beginning. In all samples, except in glass $\mathrm{P}$, XRD indicated the presence of two types of cristobalite with different crystal lattice periods, which could be evaluated from the main diffraction maximum corresponding to around $4.05 \AA$ lattice plane spacing. A significant improvement in the reliability index $(R)$ of several \% was

This article is protected by copyright. All rights reserved. 
achieved during Rietveld refinement if two cristobalites rather than one were introduced with different crystal lattice parameters, which is then assumed to represent the high- and the lowtemperature form of this structure with larger $\left(d_{011}=4.08 \AA\right)$ and smaller $\left(d_{011}=4.04 \AA\right)$ crystal lattice parameters, respectively, belonging to different tetragonal space groups ${ }^{19}$. It was, however, not possible to confirm the presence of the two different symmetries from the XRD results, because they are discriminated through the absence or presence of minor diffraction maxima which were heavily overlapping with the other phases in the samples. It is likely that the high-temperature form was stabilized by partial substitution of Si by Al (and possibly B) and "stuffing" the structure with some $\mathrm{Ca}$, as found in synthesis works ${ }^{15}$, but it was not possible to approve it by EMPA due to very small sizes of the cristobalite grains. The average crystallite size of cristobalite was typically below $100 \mathrm{~nm}$ (XRD) and it often appeared in intimate mixtures with anorthite (EMPA) where it looked like residual silica formed during the crystallization of anorthite. According to XRD, only the low-temperature form of cristobalite formed in glass P and it crystallized even faster, cf. Figure 3 and Figure 12. Both quartz and tridymite were absent from glass $\mathrm{P}$.

Quartz developed as the stable silica form from cristobalite during the prolonged annealing of samples. The samples annealed at $850^{\circ} \mathrm{C}$ were close to the transition temperature quartztridymite and also the latter silica form was found therein ${ }^{20}$. In all samples, quartz ${ }^{21}$ showed slightly increased crystal lattice parameters as was confirmed both by the results of Rietveld refinement which was self-correcting and by the measurement of one sample with the addition of quartz standard and may reflect the presence of impurities in composition and/or a strained crystal structure.

Transition from cristobalite to quartz seemed in most cases to go through a $1^{\text {st }}$-order process following the slope $\sim 1$ in the log-log-plot and was more pronounced in cf11 and cf30 than in $f 11$ and $\mathrm{c} 30 \mathrm{~b}$ respectively. The concentration of quartz was even reduced in c30b after $168 \mathrm{~h}$. Okayamalite, which is the boron analogue of gehlenite with the same basic crystal structure,

This article is protected by copyright. All rights reserved. 
appeared in the Mg-poor Ca-rich borosilicate samples c30b and cf30. It formed in c30b one of the main constituents, taking around $1 / 4$ of the volume and it started to crystallize when the amount of remnant glass was also dramatically reduced, cf. Figure 9. Chemical analysis revealed a composition close to $\mathrm{Ca}_{2} \mathrm{Al}_{0.4} \mathrm{~B}_{1.6} \mathrm{SiO}_{7}$, hence identified it as a member of the solid solution series between okayamalite and gehlenite with the former component dominating (80 mol\%). The available crystal structure data of a natural okayamalite ${ }^{22}$ were used for Rietveld refinement, but with the $20 \mathrm{~mol} \% \mathrm{Al}$ introduced at the boron site. Calcium metaborate ${ }^{23}$ was observed in the samples cf30 and c30b and in very small amount also in $\mathrm{f} 11$ annealed at $800^{\circ} \mathrm{C}$. In cf30 it dominated over okayamalite and was the main boron phase in the fully recrystallized samples. In contrast, boron was mainly present in the residual glass in the samples MCAS, f11 and cf11. Calcium metaborate has been found mainly inter-grown with cristobalite and anorthite, cf. Figure 11.

Titanite ${ }^{24}$ was observed in samples $\mathrm{f} 11$ and cf11 where the glasses contained over twice as much $\mathrm{TiO}_{2}$ compared to other samples. It appeared late in the crystallization sequence and was likely accommodating the titanium that was not absorbed by diopside, which according to Table 6 acts as a sink for titanium among the main phases (EMPA). The titanium oxide concentration in the glass phase of $\mathrm{cf} 30$ increased proportional to the decrease of the glass phase concentration, which indicates that titanium was preferentially kept in the glass and not in crystalline phases in these glasses from which borates crystallized, cf. figures 4, 7 and 10 .

Glass phase compositions developed differently as function of the devitrification, but still showed a few common features. The initial silica concentrations dropped on onset of crystallization to what the limited amount of data may indicate was a constant level around $35 \mathrm{~mol} \%$ for MCAS and $\mathrm{f} 11$ samples and to around $28 \mathrm{~mol} \%$ for $\mathrm{cf} 30$. In contrast, the silica concentration remained relatively constant for glass $\mathrm{P}$, cf. Figure 13 , and concentrations of $\mathrm{Ca}$ and $\mathrm{Mg}$ dropped at the later stages of devitrification, contrary to the trends seen in other samples. Boron concentration seemed to rise on devitrification from the initial levels to approximately $26 \mathrm{~mol} \%$ in MCAS and

This article is protected by copyright. All rights reserved. 
f11 samples at $800^{\circ} \mathrm{C}$ and $21 \mathrm{~mol} \%$ at $850^{\circ} \mathrm{C}$, and even to higher values at approximately $30 \mathrm{~mol} \%$ in cf30. Comparing figures 4 and 7 reveals that boron concentration in the residual glass phase of cf11 was equal to or higher than in $\mathrm{f} 11$, and that the calcium concentration was significantly higher when calcium metaborate started forming in $\mathrm{f} 11(\mathrm{CaO}=31 \mathrm{~mol} \%)$ than in cf11 $(\mathrm{CaO}=23$ mol\%) where no borate was formed. Calcium metaborate started to form in c30b at onset of devitrification ( $\mathrm{CaO}=32$ mole\%) after about $30 \mathrm{~h}$. The $\mathrm{Ca}: \mathrm{Mg}$ ratio in the glass phase in cf30 started at about 26 and was reduced to about 12 before the glass phase disappeared. The opposite trend was seen in MCAS and $\mathrm{f} 11$ materials where $\mathrm{Ca}: \mathrm{Mg}$ ratio started from about 3 and increased to about 8.

Glass phase separation was clearly observed in MCAS where relatively large darker droplets in the glass phase showed almost twice as much silicon, half as much boron, and less aluminum than the average glass composition (EMPA). Phase separation was less pronounced in $\mathrm{f} 11$ samples and could not be observed by microscopy in cf11 samples.

\section{Discussion}

Microstructures of the devitrified phases in the non-milled and quenched samples, f11 and Glass P, can be observed in Figures 5 and 15. After 24 hours, crystallization has taken place either within spherical borders as for Glass $\mathrm{P}$, or for $\mathrm{f} 11$ as relatively small isolated clusters, which may be characterized as apparently spherulitic. Longer aging times cause the microstructure to feature generally needle-shaped crystals that indicates a transition to more unidirectional growth of individual crystals; an understanding that may be supported by the variations of the respective Avrami parameters (n). High numbers, in the range of 4 , indicates homogeneous nucleation and 3-dimensional growth. Whether the reductions of the Avrami parameters are expected to end at 2 or 1 then depends on the spatial growth, if this is analogue to a shrinking core $(n=1)$ or evenly distributed in the volume of the glass ceramic $(n=2)^{4}$. While anorthite and diopside generally

This article is protected by copyright. All rights reserved. 
were found as longer or needle shaped crystals, silica-rich phases like quartz and cristoballite contrastingly were seen as more equiaxed crystals, which makes it difficult to link the overall Avrami parameter to more quantitative statements for the growth mechanisms. Comparing the Figures 3 and 6 show that the devitrification process in f11 was strongly influenced by the presence of a heterogeneous nucleation mechanism. Milling the hyperquenched material decreased the time for onset of crystallization by a factor of at least 10 . Both the anorthite and the diopside in cf11 reached close to their equilibrium concentrations after $24 \mathrm{~h}$ at $800^{\circ} \mathrm{C}$, which took at least $\sim 400 \mathrm{~h}$ for the $\mathrm{f} 11$ material at similar conditions. This is quite in concord with reports in literature on alkaline earth silicate glasses, where the effect of this dominant nucleation mechanism can be reduced with increasing particle size ${ }^{25}$. The crystallization of borates, as seen in c30b and cf30, is more difficult to assess in light of reports in literature that shows nucleation and growth mechanisms in boroaluminosilicate glasses ${ }^{26}$ or borosilicate glasses $^{27,28}$ are controlled mainly by homogeneous nucleation.

The signs of surface nucleation seen on micrographs of MCAS probably masks weaker signs of homogeneous nucleation and make it difficult to assess its influence, except that the onset of crystallization for both MCAS and c30f seems to appear immediately after - or even before reaching the annealing temperature, which is not observed similarly for the cf11. Results further show that all milled glass materials reached equilibrium within the 1000 hours with respect to the formation of major phases, anorthite, diopside, and wollastonite as well as the total amount of silica-phases (cristobalites and quartz). The phase transition of cristobalite to quartz and growth of less dominant phases required longer times to reach equilibrium and was also dependent on temperature, cf. Figure 3. It was also interesting to notice that the phases formed rapidly from the glass in the beginning of the devitrification seem to include considerable amounts of boron in partly defective and stuffed structures, cf. Tables 5 and 6 , which then gradually transformed or recrystallized while the boron concentration decreased.

This article is protected by copyright. All rights reserved. 
Nucleation mechanism had a visible impact on both the microstructure in the devitrified materials and on the morphology of the individual crystals, as may most clearly be seen in comparing the Figures $5 \& 8$. The insignificant proportion of heterogeneous nucleation on particle surfaces in $\mathrm{f11}$ led to a coarser microstructure, in which the different phases were less intergrown from the beginning. The coarser microstructure also led to a clearly visible phase separation in the residual glass. A similar glass phase separation may well exist in cf11, but on a much smaller size scale, below the resolution of the applied microscopy. Possible existence of phase separation in the residual glasses in cf11, c11, and MCAS may find support from the finding ${ }^{29}$ that the glass transition temperatures, $\mathrm{Tg}$, in many experimental data from borosilicate glasses are reported too high due to phase separation effects. The $\mathrm{Tg}$ of the residual glasses in cf11, $\mathrm{c} 11$, and MCAS were calculated ${ }^{30}$ to be $100-200^{\circ} \mathrm{C}$ lower than experimentally found and only $20-50{ }^{\circ} \mathrm{C}$ lower in residual glasses of cf30 and c30b.

The MCAS and f11 samples featured large euhedral crystals of compositions (EMPA) falling between those of doped cristobalite and anorthite used for fitting XRD in the Rietveld analysis. Given the intimate mixing of these two phases observed in the microscope after longer aging times, one explanation may be that crystallite sizes in the initial phases were too small to be discriminated by EMPA. It may as well be hypothesized, though, that they represent a supersilicic non-stoichiometric anorthite with vacancies in Ca sites because the amounts of the euhedral crystals matched reasonably well the amounts of anorthite derived from XRD. In both MCAS and f11, clear signs of resorption of anorthite were seen on longer aging, cf. right part of Figure 14, and EMPA measurements indicated that this phase gradually recrystallized over time into a more stoichiometric structure with less surplus of silicon. In MCAS the EMPA measurements suggested coexistence of two types of anorthite phases. Non-stoichiometric anorthite with up to $11 \% \mathrm{~A}$-site vacancy is known from previous investigations ${ }^{15}$ and its annealing in air at $1050^{\circ} \mathrm{C}$ resulted in exsolution of minute $\mathrm{SiO}_{2}$ inclusions. In another work ${ }^{31}$ limited solid solutions have been observed between $\mathrm{CaAl}_{2} \mathrm{Si}_{2} \mathrm{O}_{8}$ and $\mathrm{SiO}_{2}$ with $8 \mathrm{wt} \% \mathrm{SiO}_{2}$ in anorthite and

This article is protected by copyright. All rights reserved. 
approximately $5 \mathrm{wt} \%$ anorthite-component in cristobalite. These results, however, do not correspond with the extent of solid solution resulting from the present set of results, which supports the hypothesis that the euhedral crystals are neither a pure non-stoichiometric anorthite nor a stuffed derivative of cristobalite but most probably a non-stoichiometric anorthite with around $10 \%$ of vacancies and with minute inclusions of stuffed cristobalite or residual glass.

The solid solution substitutions in diopside and wollastonite, cf. Table 6, were generally in accordance with literature reporting ${ }^{16,}$ that $\mathrm{Si}^{4+}$ in the tetrahedral site may be substituted by $\mathrm{Al}^{3+}$, $\mathrm{Mg}^{2+}$ in the octahedral site $\mathrm{M} 1$ by e.g. $\mathrm{Al}^{3+}, \mathrm{Fe}^{3+}, \mathrm{Fe}^{2+}, \mathrm{Ti}^{4+}$, while $\mathrm{Ca}^{2+}$ in the octahedral site $\mathrm{M} 2$ can be substituted by e.g. $\mathrm{Mg}^{2+}$ and $\mathrm{Fe}^{2+}$. Boron can substitute for silicon in the tetrahedral site in clinopyroxene by the coupled substitution ${ }^{\mathrm{M} 1} \mathrm{M}^{2+}+{ }^{\top} \mathrm{Si}^{4+} \rightarrow{ }^{\mathrm{M} 1} \mathrm{M}^{3+}+{ }^{\top} \mathrm{B}^{3+}$ similarly to the Alsubstitution. In a recent work ${ }^{32}$, significant amounts of boron was found to form $\mathrm{BO}_{3}$ groups substituting for $\mathrm{SiO}_{4}$ in diopside, accompanied by a larger substitution with scandium as trivalent element in the octahedral M1 site and formation of vacancies at the M2 site. But even though diopside, being a nominally boron-free phase, accommodated the largest amounts of boron at the start of devitrification, stoichiometry calculations based on EMPA did not suggest vacancies at the Ca M2 site.

Wollastonite showed a markedly smaller substitution by boron, except in c30b, where it also maintained the substitution level throughout the annealing period, cf. Table 6.

Cristobalite crystallized readily from all glasses even though this is not the thermodynamically stable form at the annealing temperatures. Except in glass $\mathrm{P}$, where only one type, lowcristobalite, was observed, Rietveld fitting to the XRD data showed that there were two cristobalite phases with different crystal lattice parameters, cf. Tables $2 \& 5$. Cristobalite is often seen crystallizing directly from glass and glass ceramics and may be brought to room temperature without recrystallizing to quartz ${ }^{33,}$ and stuffed derivatives of cristobalite were reported to retain the high cristobalite ( $\beta$-cristobalite) symmetry on cooling ${ }^{34}$. Earlier reports also speculated on the

This article is protected by copyright. All rights reserved. 
tendency for the aluminate component to favor the cristobalite structure over the tridymite structure ${ }^{31}$. In tridymite the layers of interconnected hexagonal rings of $\mathrm{SiO}_{4}$ tetrahedra are stacked directly over one another forming the channels. The same is true for cristobalite, but here are the overlying rings of tetrahedra rotated $60^{\circ}$ relative to each other resulting in helicoidally-shaped voids, and not straight channels. Although a fully stuffed derivative of the crystal structure of tridymite exists in the form of the mineral nepheline with half of Si replaced by $\mathrm{Al}$, and the structural channels filled by $\mathrm{Na}$ and $\mathrm{K}$, it seems that the stuffed derivatives with only a small degree of substitution are more favored in the structure of cristobalite ${ }^{31}$. This is probably due to the more isolated voids for the accommodation of the additional large cations. Stabilization of $\beta$-cristobalite, given the formal stoichiometry $\mathrm{Si}_{1-x} \mathrm{Al}_{x} \mathrm{M}_{x /{ }^{n+}} \mathrm{O}_{2}$, to lower temperatures was reported with $\mathrm{M}=\mathrm{Ca}$ and $0.04<\mathrm{x}<0.08^{33}$. When $\mathrm{x}>0.08$ reflections corresponding to anorthite appeared in the XRD-patterns. This indicates the limit of solid solubility of $\mathrm{CaO}$ and/or $\mathrm{Al}_{2} \mathrm{O}_{3}$ in the cristobalite lattice.

It may be noted that according to XRD, only the low cristobalite type forms in glass $\mathrm{P}$, and it crystallizes even faster than cristobalite in other samples, cp. Figure $3 \& 12$. Both quartz and tridymite are absent from glass $\mathrm{P}$ even at the latest stages of devitrification hence, the presence of boron may promote formation of the ( $\mathrm{Ca}, \mathrm{Al})$-stabilized high-cristobalite form in other samples which, however, transforms more readily on annealing.

Both Ca and preferably Mg stabilize aluminoborosilicate glass formation by compensation of charges on B4- and Al4-units in a silicate-based structure ${ }^{35}$. In cases of cf30 and c30b, where the amount of residual glass falls below detection limit on aging at temperature, initial Mgconcentration was low and the majority of Ca was allocated in the crystalline phases. This might indicate that the higher Mg:Ca ratio stabilizes the glass phase. In MCAS and f11-materials where considerably more residual glass existed, phase separation was observed as smaller globular Sirich inclusions, in accordance with general behavior of M-borosilicate glasses ${ }^{36}$. In these materials, Mg-concentration in the glass dropped on devitrification and Ca-concentration was

This article is protected by copyright. All rights reserved. 
constant or showed a small increase. Calcium concentration of at least $30 \mathrm{~mol} \%$ in the residual glass seems to be necessary for formation of crystalline borates, cf. Figures $3,4,6,7,9,10$, which was only reached for the $f 11\left(800^{\circ} \mathrm{C}\right)$ sample, and maybe also for the cf11 $\left(850^{\circ} \mathrm{C}\right)$ sample. Devitrification of MCAS resembled devitrification of cf11 and yielded almost identical phase assemblages. The slightly higher boron concentration in MCAS was mainly leading to a more pronounced phase separation of the remnant glass. Differences are found in the higher remaining residual glass in MCAS and the faster transformation of cristobalite to quartz in cf11. Influence from the boron content in the glass on the crystallization rates can be deduced from the difference between glass $\mathrm{P}$ and the other glasses. Even though glass $\mathrm{P}$ has been hyperquenched, devitrification started immediately on aging, cf. Figure 12 , which may be compared to the other hyper-quenched material, f11 in Figure 3.

The intergrowth in cf30 of calcium metaborate and Si-rich phases, quartz, cristobalite, and anorthite, indicates that the residual glass, once it reached sufficiently high Ca-concentration, might act as a vehicle for transport of calcium from the initially formed wollastonite to the calcium metaborate.

Additionally to the inherent glass properties like viscosity, adhesion and thermal expansion, development of phase assemblages on aging with respect to both the amount and morphologies of the crystal phases are important properties to be considered if the glass ceramic materials are going to be used for sealant, as this may require rigidity in some cases and compliancy in other cases, dependent on the application. The high amounts of devitrified material and entangled microstructures in the boron-rich glasses, cf30 \& c30b, in glass $P$ and in both $c 11$ and cf11 facilitates their use in rigid sealants, for which the thermomechanical match to counterparts must be verified prior to use. A considerable time before onset of devitrification is usually desirable in SOC-stack sealing as this allows for forming both a better mechanical connection and more homogeneously distributed electrical contact between the individual components, so the relatively fast onset of devitrification in both cf11, glass $P$ and in c30b makes them less useful for This article is protected by copyright. All rights reserved. 
this purpose, unless sealing at slightly lower temperatures than $800{ }^{\circ} \mathrm{C}$ can be employed.

Excluding for a moment external factors like e.g. thermal stability of counterparts, the fragility of the vitreous glasses, as shown in Figure 2 (left) illustrates to which extent sealing temperatures can be reduced, and it may be observed that while most glasses in this lot show an almost similar degree of fragility, the two boron-rich glasses cf30 and in particular c30b exhibits higher fragility and thereby lend themselves to sealing SOC-stacks at an adequate viscosity, $\log (\eta)=6.5-7.5$ $\mathrm{Pa}^{*} \mathrm{~s}^{37}$, closer to their glass transition temperatures than the rest. Transferred into numbers of temperature range; the increased fragility of $c 30 \mathrm{~b}$ reduces the temperature gap from $\mathrm{Tg}$ to a relevant sealing temperature $(\log (\eta)=6.5 \mathrm{~Pa} * \mathrm{~s})$ to $118^{\circ} \mathrm{C}$ as opposed to being $\sim 200^{\circ} \mathrm{C}$ for the less fragile glasses (MCAS, $\mathrm{f} 11$ and $\mathrm{P})$.

Figure 2 also shows how glass fragility significantly increases on aging of MCAS as a consequence of the boron enrichment and other compositional changes. Particularly for this aged residual glass in Figure 2 (right) it may be noted that the composition with respect to the boron content lies significantly outside the optimum compositional limits for the modelling, but as the modelled $\operatorname{Tg}$ comes in fair agreement with the experimentally determined $\mathrm{Tg}, 482^{\circ} \mathrm{C}$ and $483^{\circ} \mathrm{C}$, respectively, the modelled viscosities have been accepted within the general error margin of \pm 12 ${ }^{\circ} \mathrm{C}$ provided by the modelling. As the less entangled and fibrous microstructures observed in the laboratory-analogues, MCAS and c30b, also attracts interest for sealants that must feature selfhealing or compliant properties, the increased fragility of the glassy phase in MCAS provides a reasonable base for future work and optimization of this sealant for compliant sealing, in spite this glass does not belong to the group of relatively cheap commercial glasses.

This article is protected by copyright. All rights reserved. 


\section{Conclusions and outlook}

Devitrification seemed activated primarily through heterogeneous surface nucleation and to lesser degree by homogeneous nucleation. Adding surface nucleation sites, by milling hyperquenched glass fibres, accelerated the onset of devitrification by almost an order of magnitude, hence reduced the time for viscous flow of the glass sealant. In the absence of deliberately incorporated surface nucleation in $\mathrm{f} 11$ and glass $\mathrm{P}$, the higher boron content of the former delayed the onset of crystallization. Characterization of the devitrification processes by the Avrami parameter suggested that heterogeneous surface nucleation, when present, largely dominated the growth kinetics, and indicated that in the absence of surface-induced devitrification three-dimensional growth at the onset of devitrification gradually changed towards one-dimensional growth in later stages. Observation of microstructures supports this hypothesis.

Most glasses developed entangled and fibrous microstructures with little or no residual glass phase, which are adequate for rigid sealants, and only one of the laboratory analogue glasses, MCAS, developed microstructures with both more equiaxed grains and a considerable amount of residual glass phase, which may be adequate for more compliant and self-healing sealants as often required in SOC-applications.

Ageing temperature influences crystallization rates, but the glass ceramic materials with comparable compositions reached the same equilibrium within the 1000 hours with respect to principal distribution of elements and the amounts of major phases anorthite, diopside, and wollastonite as well as the total amount of silica-phases, cristobalite, tridymite, and quartz. Recrystallization of ( $\mathrm{Ca}, \mathrm{Al})$-bearing cristobalite to quartz, and growth of less dominant phases, required longer times to reach equilibrium and was influenced by ageing temperature, possibly through glass viscosity. The defect structure achieved through Al,B-substitution and Ca-stuffing seemed to facilitate the transformation of metastable cristobalite to quartz.

This article is protected by copyright. All rights reserved. 
Even smaller variations in initial glass chemistry significantly influenced the development of phases. Particularly the ratio between magnesium and calcium determined the proportion of the diopside and wollastonite, which crystallized from the glass. This is likely due to absence of a solid solution between these two chain-silicate structure types.

The crystallization of the calcium borate phases seems to require a Ca-concentration of over 30 mol\% in the glass. In cases where magnesium concentration in the glass fell to a level of $1 \mathrm{~mol} \%$, the amount of residual glass phase decreased to below detection limit.

According to the electron microprobe analyses, most of the nominally boron-free phases in highboron glasses incorporated small amounts of boron into their structures during the initial devitrification. The boron content, however, tended to disappear with time at temperature. This result indicates that devitrification occurred directly from the boron-containing glass, too fast to allow for diffusion to establish thermodynamic equilibria. The phase assemblages then slowly moved towards equilibria, which were established over longer aging periods and through recrystallization. Resorption and recrystallization did not seem to dramatically alter initially formed microstructures, hence mechanical properties of the sealant, within the time frame of this investigation.

The quantification of phase assemblages assessed through Rietveld refinement of XRD spectra and using a "pseudo-quartz" structural model for the vitreous phases provided a useful method, which produced results at an acceptable level of confidence. However, the method was not optimized to give additional information about the amounts of the separated glass phases, nor was the effect of minor constituents in the glass ( $\mathrm{Na}, \mathrm{K}, \mathrm{F}, \mathrm{Fe}, \mathrm{Ti}, \mathrm{Mn}$ and P) systematically investigated in this work.

Although the present work investigated a relatively complex system, the obtained results can form a good base for comparison with results from modelling phase assemblages from existing thermodynamic data. This will give a good indication to whether it is possible to establish a more generalized approach to prediction of crystallization in alkaline earth boroaluminosilicate glasses.

This article is protected by copyright. All rights reserved. 


\section{Acknowledgement}

L.J.H. Pedersen, H. Almind and A. Berger from the Department of Geography and Geology,

University of Copenhagen as well as C.G. Sørensen, E. Abdellahi and P.H. Nielsen from Technical University of Denmark are gratefully acknowledged for skillful assistance with sample preparation, XRD, electron microprobe and thermal analyses. L.J.H. Pedersen, M. D. Jensen, J. G. Larsen, Y. Yue, N. Lönnroth, E. Makovicky and M. N. Svenson are all acknowledged for Inspiring discussions and stimulating support.

\section{Literature}

[1] Larsen J G, Olsen C, Jensen M D. Solid oxide fuel cell stack having a glass sealant composition. U.S. Patent 8,163,436 B2. 2012 (patent)

[2] Nielsen J U, Larsen J G. Sealing glass for solid oxide electrolysis cell stacks. U. S. Patent US2012/0193223 A1 2012 (patent)

[3] Ozawa T. Kinetics of non-isothermal crystallization, Polymer, (1971) 12:150-158

[4] Matusita K, Sakka S. Kinetic study on crystallization of glass by differential thermal analysis criterion on application of Kissinger plot. J. of Non-Crystalline solids, (1980) 38\&39:741-746

[5] Pascual M J, Pascual L, Durán A. Determination of the viscosity-temperature curve for glasses on the basis of fixed viscosity points determined by hot stage microscopy. Phys. Chem. Glasses, (2001) 42:61-6

[6] Fluegel A. Glass viscosity calculation based on a global statistical modelling approach. Eur. J. Glass Sci. Technol. A (2007) 48:1:13-30

[7] Garca-Coln L S, del Castillo L F, Goldstein P. Theoretical basis for the Vogel-Fulcher-Tammann equation, Phys. Rev. (1989) B 40:7040-7044

[8] Goldstein, J.I., Newbury, D.E., Joy, D.C., Lyman, C.E., Echlin, P., Lifshin, E., Sawyer, L. \& Michael, J.R., Scanning Electron Microscopy and X-Ray Microanalysis, 3rd edition, (Corr. 4th printing edition 2007). Springer

[9] Rietveld, H.M., A profile refinement method for nuclear and magnetic structures, J. of Applied Crystallography, (1969) 2:65-71.

[10] Jenkins, R. \& Snyder, R.L., Introduction to X-ray Powder Diffractometry, John Wiley \& Sons, Inc., (1996)

[11] Balić-Žunić T. Quantitative powder diffraction phase analysis with a combination of the Rietveld method and the addition method, Powder Diffraction (2002) 17:287-289.

[12] Horst, W., Tagai, T., Korekawa, M., Jagodzinski, H., Modulated structure of a plagioclase An52: Theory and structure determination, Zeitsch. für Kristallographie (1981) 157:233-250.

This article is protected by copyright. All rights reserved. 
[13] Angel, R.J., Carpenter, M.A., Finger, L.W., Structural variation associated with compositional variation and order-disorder behavior in anorthite-rich feldspars, American Mineralogist, (1990) 75:150-162.

[14] Ito, J., High temperature solvent growth of anorthite on the join $\mathrm{CaAl}_{2} \mathrm{Si}_{2} \mathrm{O}_{8}-\mathrm{SiO}_{2}$, Mineralogy and Petrology, (1976) 59:187-194

[15] San, O., Özgür, C., Investigation of a high stable $\beta$-cristobalite ceramic powder from CaO-Al2O3SiO2 system, J. of the Eur. Cer. Soc. (2009) 29:2945-2949.

[16] Cameron, M., Papike J.J., Crystal chemistry of silicate pyroxenes, Mineral. Soc. Am. Rev. Mineral. (1980) 2:5-92

[17] Ahn, Y.P., Kim, B.-H., Ishizowa, N., Structure refinements of solid solutions in the system CaO$\mathrm{MgO}-2 \mathrm{SiO}_{2}-\mathrm{Al}_{2} \mathrm{O}_{3}$, J. of the Korean Ceramic Society, (1986) 23:25-34.

[18] Ohashi, Y., Polysynthetically-Twinned Structures of Enstatite and Wollastonite, Phys. and Chem. of Minerals, (1984) 10:217-229.

[19] Coh, S., Vanderbilt, D., Structural stability and lattice dynamics of SiO2 cristobalite, Phys. Rev., Serie 3. B - Condensed Matter, (2008) 78:54117-31.

[20] Graetsch, H., Topalovic-Dierdorf, I., 29Si MAS NMR spectrum and superstructure of modulated tridymite L3-To(MX-1), Eur. J. of Mineralogy, (1996) 8:103-113.

[21] Le Page, Y., Donnay, G., Refinement of the crystal structure of low-quartz, Acta Crystallographica B (1976) 32:2456-2459.

[22] Giuli, G., Bindi, L., Bonazzi P., Rietveld refinement of okayamalite, $\mathrm{Ca}_{2} \mathrm{SiB}_{2} \mathrm{O}_{7}$ : Structural evidence for the B/Si ordered distribution, Am. Mineralogist, (2000) 85:1512-1515.

[23] Kirfel, A., The electron density distribution in calcium metaborate, $\mathrm{Ca}\left(\mathrm{BO}_{2}\right)_{2}$, Acta Crystallographica B, (1987) 43:333-343.

[24] Taylor, M., Brown, G.E., High-temperature structural study of the P2_1/a - A2/a phase transition in synthetic titanite, $\mathrm{CaTiSiO}_{5} \mathrm{~T}=270 \mathrm{degC}, \mathrm{Am}$. Mineralogist (1976) 61:435-447

[25] Koga, N., Sestrik, J., Strnad, Z., Kinetics of crystallization in the soda-lime-silica system: Part 1. $\mathrm{Na}_{2} \mathrm{O}-\mathrm{CaO}-2 \mathrm{SiO}_{2}$ and $\mathrm{Na}_{2} \mathrm{O}-\mathrm{CaO}-3 \mathrm{SiO}_{2}$ glasses by DTA, Thermochimica Acta (1992) 203:361-372

[26] Sooksaen, P., Structure and crystallization of borate-based glasses for machinable material applications., Int. J. of Appl. Phys. and Math.,(2012) 2:89-92

[27] Hernández-Crespo, M., Romero, M., Rincon, J.Ma., Nucleation and crystal growth of glasses produced by a generic plasma-arc process, J. Eur. Cer. Soc, (2006) 26:1679-1685

[28] Krzmanc, M.M., Dosler, U., Suvorov, D., "The nucleation and crystallization of $\mathrm{MgO}-\mathrm{B}_{2} \mathrm{O}_{3}-\mathrm{SiO}_{2}$ glass, J. Eur. Cer. Soc. (2011) 31:2211-2219

[29] Fluegel, A., Glass viscosity calculation based on a global statistical modelling approach, Eur. J. Glass Sci. Technol. A (2007) 48:13-30.

[30] Fluegel, A., Varshneya, A. K., Earl, D. A., Seward, T. P., Oksoy, D., Improved compositionproperty relations in silicate glasses, part I: Viscosity, Ceramic Transactions (2005) 170:129-143.

[31] Saltzberg, M.A., Bors, S.L., Bergna, H. \& Winchester, S.C., Synthesis of chemically stabilized cristobalite, J. Am. Cer. Soc. (1992) 75:89-95

[32] Hålenius, U., Skogby, H., Edén, M., Nazzareni, S., Kristiansson, P. \& Resmark, J., Coordination of boron in nominally boron-free rock forming silicates s: Evidence for incorporation of $\mathrm{BO}_{3}$ groups in clinopyroxene, Geochimica et Chosmochimica Acta. (2010) 74:5672-5679.

[33] Höland W, Beall G. Glass-Ceramic Technology. The American Ceramic Society, Westerville, $\mathrm{OH}$, (2002)

[34] D. Maniu, D, T. Iliescua, I. Ardeleana, S. Cinta-Pinzarua, N. Tarcea, W. Kiefer, Raman study on $\mathrm{B}_{2} \mathrm{O}_{3}-\mathrm{CaO}$ glasses, J. of Molecular Structure (2003) 651-653:485-488

This article is protected by copyright. All rights reserved. 
[35] Wu, J., Potuzak, M. and Stebbins, J.F. High-temperature in situ 11B NMR study of network dynamics in boron-containing glass-forming liquids, J. of Non-Cryst. Solids (2011) 357:39443951.

[36] Osborn E F. The system $\mathrm{CaSiO}_{3}$-diopside-anorthite. Am. J. Sci. (1942) 240;751-788.

[37] Flugel A, Dolan MD, Varshneya AK, Zheng Y, Coleman N, Hall M, Earl D, Misture ST. Development of an improved devitrifiable fuel cell sealing glass I. Bulk properties, J. Electrochem. Soc. (2007) 154:B601-608.

\section{Table and figure captions}

Table 1: Glass compositions in mol\% based on data from suppliers* or determined by wet-chemical analysis** or by EMPA including used standards.

Table 2: Crystal structure data and lattice parameters for the observed crystalline phases.

Table 3: List of rate constants, $A$, in the equation $\log [i]=A \log (t)+B$, indicating the concentration (vol\%) of substance "i" as function of time " $\mathrm{t}$ " as depicted in figures $3,6,9$ and 12.

Table 4: Avrami parameters, $n$, according to the methods of Ozawa and Matusita et al., ${ }^{3,4}$.

Table 5: Stoichiometry of anorthite (plagioclase) as function of time at $800^{\circ} \mathrm{C}$ calculated from EMPAresults.

Table 6: Stoichiometry of diopside and wollastonite as function of time at $800^{\circ} \mathrm{C}$ calculated from EMPA-measurements.

Figure 1: Rietveld fitting of the glass phase in sample MCAS by the "pseudo-quartz" data. Scattered (blue): experimental data; Average (red): fitted data; Grey: background.

Figure 2: Result from modelling ${ }^{6}$ the viscosities of glasses above the glass transition temperatures (left) and modelling viscosity of a selected residual glass after annealing for $336 \mathrm{~h}$ at $800{ }^{\circ} \mathrm{C}$ (right).

Figure 3: Volume fraction of crystalline phases and remaining glass as function of time for the fiberglass $\mathrm{f} 11$ at $800^{\circ} \mathrm{C}$ (left) and at $850^{\circ} \mathrm{C}$ (right). Ca-metaborate, titanate and quartz all reach about the same concentration $\left(1.8,1.6,1.9 \%\right.$, respectively) after 1008 hours at $800^{\circ} \mathrm{C}$ (left figure)

Figure 4: Metal-oxide concentration in the remnant glass phase as function of time for the fiber-glass f11 at $800^{\circ} \mathrm{C}$ (left) and at $850^{\circ} \mathrm{C}$ (right).

Figure 5: Back scattered electron (BSE) micrographs of $\mathrm{f} 11$ after $336 \mathrm{~h}$ at $800^{\circ} \mathrm{C}$ (left). Diopside (light) is evenly distributed and a $\mathrm{SiO}_{2}$-cluster (dark) is located in the center. Anorthite (semi-dark) is intergrown with a darker phase, and scattered throughout the section is remnant glass, which shows signs of phase separation or growth of fine darker crystalline phases.

F11 after $24 \mathrm{~h}$ at $850^{\circ} \mathrm{C}$ (right). Diopside (light) and anorthite (semi-dark) have started to crystallize in a glass matrix, which has a darker color around the crystallizing phases. The relatively large diopside and anorthite crystals indicate crystallization close to eutectic.

This article is protected by copyright. All rights reserved. 
Figure 6: Volume fraction of crystalline phases and remaining glass as function of time for the milled fiber-glass cf 11 at $800^{\circ} \mathrm{C}$ (left) and at $850^{\circ} \mathrm{C}$ (right).

Figure 7: Metal-oxide concentration in the remnant glass phase as function of time for the milled fiber-glass cf 11 at $800^{\circ} \mathrm{C}$ (left) and at $850^{\circ} \mathrm{C}$ (right).

Figure 8: Back scattered electron (BSE) micrographs of cf11 after $24 \mathrm{~h}$ (left) and $336 \mathrm{~h}$ (right) at $800^{\circ} \mathrm{C}$, in which diopside (light), anorthite (semi-dark) and silica (dark) phases are evenly distributed in a semi-dark glass phase.

Figure 9: Volume fraction of crystalline phases and remaining glass as function of time for the milled fiber-glass cf30 (left) and the relatively slowly cooled milled glass c30b (right) as function of time at $800^{\circ} \mathrm{C}$.

Figure 10: Metal-oxide concentration in the remnant glass phase as function of time for the milled fiber-glass cf30 (left) and the relatively slowly cooled milled glass c30b (right) as function of time at $800^{\circ} \mathrm{C}$.

Figure 11: BSE image of the c30b sample (left) annealed for 1 week at $800^{\circ} \mathrm{C}$. Wollastonite (light), okayamalite (semi-light) and a semi-dark phase (anorthite) growing into a residual glass areas also containing a dark phase.

Back scattered electron (BSE) micrographs of the cf30 sample (right) after $1008 \mathrm{~h}$ at $800{ }^{\circ} \mathrm{C}$ features wollastonite (light), anorthite (semi-dark) and darker silica-phases, which are sometimes inter-grown with calcium metaborate (dark).

Figure 12: Volume fraction of crystalline phases and remaining glass as function of time for the milled glass MCAS as function of time at $800^{\circ} \mathrm{C}$ (left) and the as-received glass $\mathrm{P}$ at $850^{\circ} \mathrm{C}$ (right).

Figure 13: Metal-oxide concentration in the remnant glass phase as function of time for the milled glass MCAS at $800^{\circ} \mathrm{C}$ (left) and the hyper-quenched glass $\mathrm{P}$ at $850^{\circ} \mathrm{C}$ (right). Phase separation was observed in MCAS. Boron concentrations were estimated from residuals and reflect average values.

Figure 14: Back scattered electron (BSE) micrograph of the MCAS after $24 \mathrm{~h}$ at $800^{\circ} \mathrm{C}$ (left). Large glass volumes show darker reaction rims and internal growth of anorthite (semi-light crystal close to the center of the image). Diopside (light) in grain boundaries. MCAS after $336 \mathrm{~h}$ at $800^{\circ} \mathrm{C}$ (right) shows clear signs of heterogeneous crystallization of diopside (light) and anorthite (semi-dark) partly resorbed and with disintegrated interior.

Figure 15: Back scattered electron (BSE) micrograph of glass $\mathrm{P}$ after $4 \mathrm{~h}$ at $850^{\circ} \mathrm{C}$ (left) showing devitrified domains in a grey glass matrix. Glass $\mathrm{P}$ after $336 \mathrm{~h}$ at $850^{\circ} \mathrm{C}$ (right) only wollastonite (light) and darker glass areas with high boron content have been identified by EMPA. The dendritic crystals are believed to be plagioclase and cristobalite in intergrowth.

This article is protected by copyright. All rights reserved. 
Table 1: Glass compositions in mol\% based on data from suppliers* or determined by wet-chemical analysis** or by EMPA including used standards.

\begin{tabular}{|l|c|c|c|c|c|c|c|c|c|c|c|c|}
\hline Glass & $\mathrm{SiO}_{2}$ & $\mathrm{CaO}$ & $\mathrm{Al}_{2} \mathrm{O}_{3}$ & $\mathrm{~B}_{2} \mathrm{O}_{3}$ & $\mathrm{MgO}$ & $\mathrm{Na}_{2} \mathrm{O}$ & $\mathrm{K}_{2} \mathrm{O}$ & $\mathrm{F}_{2}$ & $\mathrm{Fe}_{2} \mathrm{O}_{3}$ & $\mathrm{TiO}_{2}$ & $\mathrm{MnO}$ & $\mathrm{P}_{2} \mathrm{O}_{5}$ \\
\hline $\mathrm{f} 11$ & 56.1 & 18.8 & 9.5 & 7.9 & 6.6 & 0.46 & 0.31 & $0.05^{*}$ & 0.2 & 0.63 & & \\
\hline $\mathrm{Cf} 11$ & 55.9 & 18.7 & 9.6 & 8.4 & 6.5 & 0.46 & 0.25 & $0.05^{*}$ & $0.3^{*}$ & $0.6^{*}$ & & \\
\hline $\mathrm{cf30}$ & 54.9 & 25.1 & 9.7 & 8.9 & 0.99 & 0.18 & 0.12 & & $0.08^{*}$ & $0.24^{*}$ & & \\
\hline $\mathrm{c} 30 \mathrm{~b}$ & 52.7 & 26.4 & 9.4 & 9.3 & 1.1 & 0.26 & 0.14 & & 0.13 & 0.24 & $0.04^{* *}$ & $0.02^{* *}$ \\
\hline $\mathrm{MCAS}$ & $53.7^{* * *}$ & $18.3^{* *}$ & $9.59^{* *}$ & $10.5^{* *}$ & $6.62^{* *}$ & $0.51^{* *}$ & $0.27^{* *}$ & & $0.24^{* *}$ & $0.24^{* *}$ & & $0.04^{* *}$ \\
\hline $\mathrm{MCAS}$ & 53.3 & 18.1 & 10.2 & 10.5 & 6.6 & 0.40 & 0.25 & & & & & \\
\hline Glass P & 61.2 & 23.8 & 6.76 & 1.35 & 5.0 & 1.48 & 0.33 & & & & & \\
\hline Standard & $\begin{array}{c}\text { wolla- } \\
\text { stonite }\end{array}$ & $\begin{array}{c}\text { wolla- } \\
\text { stonite }\end{array}$ & albite & MCAS & olivine & albite & orthoclase & & hematite & rutile & & \\
\hline
\end{tabular}

Table 2: Crystal structure data and lattice parameters for the observed crystalline phases.

\begin{tabular}{|c|c|c|c|c|c|c|c|c|c|}
\hline Phase & $a(\AA)$ & $b(\AA)$ & $c(\AA)$ & $\alpha\left(^{\circ}\right)$ & $B\left(^{\circ}\right)$ & $\gamma\left(\left(^{\circ}\right)\right.$ & $\mathrm{V}_{\mathrm{uc}}\left(\AA^{3}\right)$ & $\begin{array}{l}\text { Space } \\
\text { group }\end{array}$ & $\begin{array}{c}\text { data } \\
\text { source }\end{array}$ \\
\hline anorthite & $8.131-8.172$ & $12.816-12.856$ & $14.123-14.154$ & $93.3-93.2$ & $115.9-115.8$ & $90.3-91.2$ & 1322-1335 & I-1 & [10] \\
\hline plagioclase & $8.160-8.149$ & $12.808-12.899$ & 7.096-7.108 & $93.6-93.2$ & $115.7-115.8$ & $89.5-88.9$ & $667-672$ & C-1 & [9] \\
\hline Diopside & $9.642-9.736$ & $8.858-8.920$ & 5.279-5.255 & & $106.3-105.9$ & & $432-439$ & $\mathrm{C} 2 / \mathrm{c}$ & [13] \\
\hline wollastonite & 7.865-7.916 & $7.283-7.313$ & $6.998-7.051$ & $89.6-89.9$ & 95.2 & 103.4 & $388-395$ & P-1 & [14] \\
\hline cristobalite- $\alpha$ & $4.975-4.996$ & & $6.934-7.006$ & & & & $172-175$ & $P 4_{1} 2_{1} 2$ & [15] \\
\hline cristobalite- $\beta$ & $4.939-4.982$ & & $7.120-7.278$ & & & & $175-178$ & $\mathrm{I}-42 \mathrm{~d}$ & [15] \\
\hline okayamalite & $7.296-7.300$ & & $4.845-4.847$ & & & & 258 & $\mathrm{P}-42_{1} \mathrm{~m}$ & [18] \\
\hline Quartz & $4.915-4.934$ & & $5.407-5.420$ & & & & $113-114$ & $\mathrm{P}_{2} 2$ & [17] \\
\hline Tridymite & 15.02 & 8.553 & 16.38 & 90 & 92.3 & 90 & 2103 & C1 & [16] \\
\hline Titanite & 7.042 & 8.683 & 6.532 & & 113.8 & & 366 & $\mathrm{P} 2{ }_{1} / \mathrm{a}$ & [20] \\
\hline Ca-borate & 6.223 & 11.59 & 4.277 & & & & 309 & Pnca & [19] \\
\hline
\end{tabular}

This article is protected by copyright. All rights reserved. 
Table 3: List of rate constants, $A$, in the equation $\log [i]=A \log (t)+B$, indicating the concentration of substance " $i$ " as function of time " $t$ " as depicted in figures $3,6,9$ and 12 .

\begin{tabular}{|l|c|c|c|c|c|c|c|c|}
\hline & $\begin{array}{c}\mathrm{cf11} \\
800 \mathrm{C}\end{array}$ & $\begin{array}{c}\mathrm{cf11} \\
850 \mathrm{C}\end{array}$ & $\begin{array}{c}\mathrm{F} 11 \\
800 \mathrm{C}\end{array}$ & $\begin{array}{c}\mathrm{F} 11 \\
850 \mathrm{C}\end{array}$ & $\begin{array}{c}\text { MCAS } \\
800 \mathrm{C}\end{array}$ & $\begin{array}{c}\mathrm{Cf30} \\
800 \mathrm{C}\end{array}$ & $\begin{array}{c}\text { C30b } \\
800 \mathrm{C}\end{array}$ & $\begin{array}{c}\text { Glass } \\
\mathrm{P}\end{array}$ \\
\hline Glass & -0.5 & $-0,6$ & -0.8 & -0.9 & -0.3 & -2.8 & -2.8 & -1.0 \\
\hline Diopside & 1.8 & 3.7 & - & 2.0 & 1.1 & - & 1.0 & 0.6 \\
\hline Wolastonite & - & - & - & - & - & - & 1.4 & 1.0 \\
\hline Anorthite & 1.8 & 3.7 & - & 1.7 & 4.0 & 1.5 & 1.0 & 2.0 \\
\hline $\begin{array}{l}\text { Ca,Al } \\
\text { Cristobalite }\end{array}$ & 1.1 & 1.2 & 1.2 & - & 1.0 & - & 1.2 & - \\
\hline $\begin{array}{l}\text { Christobalite, } \\
\text { low }\end{array}$ & 1.1 & 1 & 1.2 & - & 0.7 & 0.8 & 0.5 & 1.1 \\
\hline Quartz & 1.0 & 1.1 & 1.2 & 0.3 & 1.4 & 0.7 & 0.6 & - \\
\hline Okayamalite & - & - & - & 0.6 & - & - & 1.7 & - \\
\hline Ca-metaborate & - & - & - & - & - & 0.5 & 0.5 & - \\
\hline Titanite & - & - & 0.9 & 0.2 & - & 1.4 & - & - \\
\hline
\end{tabular}

Table 4: Avrami parameters, $n$, according to the method of Matusita et al. ${ }^{1,2}$. Glass $P$ exhibit two separate crystallization processes.

\begin{tabular}{|c|c|c|c|c|c|c|c|c|c|c|c|c|c|c|c|}
\hline \multicolumn{2}{|l|}{ cf11 } & \multicolumn{2}{|l|}{$\mathrm{f} 11$} & \multicolumn{2}{|l|}{ MCAS } & \multicolumn{2}{|l|}{ cf30 } & \multicolumn{2}{|l|}{ f30 } & \multicolumn{2}{|l|}{ C30b } & \multicolumn{2}{|c|}{ Glass $P, 1^{\text {st }}$} & \multicolumn{2}{|c|}{ Glass $P, 2^{\text {nd }}$} \\
\hline $\begin{array}{c}\text { Temp } \\
\mathrm{K}\end{array}$ & $\mathrm{n}$ & $\begin{array}{c}\text { Temp } \\
\mathrm{K}\end{array}$ & $\mathrm{n}$ & $\begin{array}{c}\text { Temp } \\
\mathrm{K}\end{array}$ & $n$ & $\begin{array}{c}\text { Temp } \\
\mathrm{K}\end{array}$ & $\mathrm{n}$ & $\begin{array}{c}\text { Temp } \\
\text { K }\end{array}$ & $\mathrm{n}$ & $\begin{array}{c}\text { Temp } \\
\text { K }\end{array}$ & $n$ & $\begin{array}{c}\text { Temp } \\
\text { K }\end{array}$ & $\mathrm{n}$ & $\begin{array}{c}\text { Temp } \\
\mathrm{K}\end{array}$ & $\mathrm{n}$ \\
\hline 1183 & 4.1 & 1203 & 4.3 & 1163 & 1.4 & 1245 & 0.8 & 1083 & 3.1 & 1123 & 1.1 & \begin{tabular}{|l|l}
1183 \\
\end{tabular} & 4.0 & 1283 & 1.8 \\
\hline 1203 & 2.2 & 1223 & 2.8 & 1183 & 1.2 & 1263 & 0.5 & 1093 & 1.6 & 1143 & 1.1 & \begin{tabular}{|l}
1203 \\
\end{tabular} & 1.9 & 1303 & 1.5 \\
\hline 1243 & 1.2 & 1243 & 2.1 & 1203 & 1.0 & 1283 & 0.5 & 1103 & 1.0 & 1163 & 1.0 & 1223 & 1.4 & 1343 & 1.5 \\
\hline & & 1283 & 2.0 & 1223 & 1.0 & 1303 & 1.0 & 1113 & 0.8 & 1183 & 1.1 & 1243 & 0.9 & 1363 & 1.5 \\
\hline & & 1323 & 1.8 & & & & & & & & & & & 1383 & 1.3 \\
\hline
\end{tabular}

Table 5: Stoichiometry of anorthite (plagioclase) as function of time at $800^{\circ} \mathrm{C}$ calculated from EMPAresults.

\begin{tabular}{|c|c|}
\hline f11 $800^{\circ} \mathrm{C}$ & Anorthite (plagioclase) \\
\hline $168 \mathrm{~h}$ & $\mathrm{Ca}_{0.65} \mathrm{Na}_{0.06} \mathrm{~K}_{0.03} \mathrm{Mg}_{0.09} \square_{0.17}\left(\mathrm{Fe}^{3+}{ }_{0.01} \mathrm{Ti}_{0.01} \mathrm{Al}_{1.07} \mathrm{~B}_{0.08} \mathrm{Si}_{2.83}\right) \mathrm{O}_{8}$ \\
\hline $336 \mathrm{~h}$ & $\mathrm{Ca}_{0.62} \mathrm{Na}_{0.03} \mathrm{~K}_{0.04} \mathrm{Mg}_{0.05} \square_{0.26}\left(\mathrm{Fe}_{0.01}^{3+} \mathrm{Al}_{1.12} \mathrm{Si}_{2.87}\right) \mathrm{O}_{8}$ \\
\hline $1008 \mathrm{~h}$ & $\mathrm{Ca}_{0.92} \mathrm{Na}_{0.06} \mathrm{~K}_{0.01} \mathrm{Mg}_{0.01}\left(\mathrm{Fe}_{0.02}^{3+} \mathrm{Al}_{1.91} \mathrm{Si}_{2.07}\right) \mathrm{O}_{8}$ \\
\hline cf11 $800^{\circ} \mathrm{C}$ & Anorthite (plagioclase) \\
\hline $24 \mathrm{~h}$ & $\mathrm{Ca}_{0.63} \mathrm{Na}_{0.07} \mathrm{~K}_{0.01} \mathrm{Mg}_{0.10} \square_{0.19}\left(\mathrm{Fe}^{3+}{ }_{0.01} \mathrm{Al}_{1.14} \mathrm{~B}_{0.14} \mathrm{Si}_{2.71}\right) \mathrm{O}_{8}$ \\
\hline $336 \mathrm{~h}$ & $\mathrm{Ca}_{0.87} \mathrm{Na}_{0.10} \mathrm{~K}_{0.01} \mathrm{Mg}_{0.02}\left(\mathrm{Al}_{1.75} \mathrm{~B}_{0.09} \mathrm{Si}_{2.15}\right) \mathrm{O}_{8}$ \\
\hline $1008 \mathrm{~h}$ & $\mathrm{Ca}_{0.89} \mathrm{Na}_{0.09} \mathrm{~K}_{0.01} \mathrm{Mg}_{0.01}\left(\mathrm{Ti}_{0.01} \mathrm{Al}_{1.88} \mathrm{Si}_{2.11}\right) \mathrm{O}_{8}$ \\
\hline cf30 $800^{\circ} \mathrm{C}$ & Anorthite (plagioclase) \\
\hline $168 \mathrm{~h}$ & $\mathrm{Ca}_{0.93} \mathrm{Na}_{0.02} \mathrm{~K}_{0.01} \mathrm{Mg}_{0.04}\left(\mathrm{Fe}_{0.02}^{3+} \mathrm{Ti}_{0.01} \mathrm{Al}_{1.64} \mathrm{~B}_{0.25} \mathrm{Si}_{2.08}\right) \mathrm{O}_{8}$ \\
\hline $336 \mathrm{~h}$ & $\mathrm{Ca}_{0.95} \mathrm{Na}_{0.03} \mathrm{~K}_{0.01} \mathrm{Mg}_{0.01}\left(\mathrm{Fe}_{0.01}^{3+} \mathrm{Al}_{1.73} \mathrm{~B}_{0.07} \mathrm{Si}_{2.19}\right) \mathrm{O}_{8}$ \\
\hline $1008 \mathrm{~h}$ & $\mathrm{Ca}_{0,96} \mathrm{Na}_{0.02} \mathrm{~K}_{0.01} \mathrm{Mg}_{0.01}\left(\mathrm{Al}_{1.94} \mathrm{Si}_{2.06}\right) \mathrm{O}_{8}$ \\
\hline c30b $800^{\circ} \mathrm{C}$ & Anorthite (plagioclase) \\
\hline
\end{tabular}

This article is protected by copyright. All rights reserved. 


\begin{tabular}{|c|c|}
\hline $24 \mathrm{~h}$ & $\mathrm{Ca}_{0.95} \mathrm{Na}_{0.05} \mathrm{Al}_{1.96} \mathrm{Si}_{2.04} \mathrm{O}_{8}$ \\
\hline $168 \mathrm{~h}$ & $\mathrm{Ca}_{0.92} \mathrm{Na}_{0.06} \mathrm{~K}_{0.01} \mathrm{Mg}_{0.01}\left(\mathrm{Al}_{1.82} \mathrm{~B}_{0.01} \mathrm{Si}_{2.17}\right) \mathrm{O}_{8}$ \\
\hline $336 \mathrm{~h}$ & $\mathrm{Ca}_{0.93} \mathrm{Na}_{0.06} \mathrm{Mg}_{0.01}\left(\mathrm{Fe}^{3+}{ }_{0.01} \mathrm{Al}_{1.83} \mathrm{~B}_{0.05} \mathrm{Si}_{2.11}\right) \mathrm{O}_{8}$ \\
\hline $1008 \mathrm{~h}$ & $\mathrm{Ca}_{0.91} \mathrm{Na}_{0.08} \mathrm{Mg}_{0.01}\left(\mathrm{Fe}^{3+}{ }_{0.01} \mathrm{Al}_{1.74} \mathrm{~B}_{0.05} \mathrm{Si}_{2.20}\right) \mathrm{O}_{8}$ \\
\hline MCAS $800^{\circ} \mathrm{C}$ & Anorthite (plagioclase) \\
\hline $4 \mathrm{~h}$ & $\mathrm{Ca}_{0.89} \mathrm{Na}_{0.08} \mathrm{Mg}_{0.03}\left(\mathrm{Fe}_{0.03}^{3+} \mathrm{Al}_{1.78} \mathrm{Si}_{2.19}\right) \mathrm{O}_{8}$ \\
\hline $24 \mathrm{~h}$ & $\begin{array}{l}\mathrm{Ca}_{0.93} \mathrm{Na}_{0.05} \mathrm{Mg}_{0.02}\left(\mathrm{Al}_{1.89} \mathrm{Si}_{2.11}\right) \mathrm{O}_{8} \\
\mathrm{Ca}_{0.67} \mathrm{Na}_{0.06} \mathrm{~K}_{0.02} \mathrm{Mg}_{0.07} \square_{0.24}\left(\mathrm{Fe}_{0.01}^{3+} \mathrm{Al}_{1.13} \mathrm{~B}_{0.32} \mathrm{Si}_{2.58}\right) \mathrm{O}_{8}\end{array}$ \\
\hline $168 \mathrm{~h}$ & $\begin{array}{l}\mathrm{Ca}_{0.91} \mathrm{Na}_{0.07} \mathrm{Mg}_{0.02}\left(\mathrm{Al}_{1.86} \mathrm{Si}_{2.14}\right) \mathrm{O}_{8} \\
\mathrm{Ca}_{0.67} \mathrm{Na}_{0.09} \mathrm{~K}_{0.02} \mathrm{Mg}_{0.05} \square_{0.17}\left(\mathrm{Fe}^{3+}{ }_{0.01} \mathrm{Al}_{1.26} \mathrm{~B}_{0.17} \mathrm{Si}_{2.58}\right) \mathrm{O}_{8}\end{array}$ \\
\hline $336 \mathrm{~h}$ & $\begin{array}{l}\mathrm{Ca}_{0.91} \mathrm{Na}_{0.07} \mathrm{Mg}_{0.02}\left(\mathrm{Al}_{1.81} \mathrm{Si}_{2.19}\right) \mathrm{O}_{8} \\
\mathrm{Ca}_{0.63} \mathrm{Na}_{0.1} \mathrm{~K}_{0.02} \mathrm{Mg}_{0.05} \square_{0.2}\left(\mathrm{Fe}^{3+}{ }_{0.01} \mathrm{Al}_{1.19} \mathrm{~B}_{0.18} \mathrm{Si}_{2.6}\right) \mathrm{O}_{8}\end{array}$ \\
\hline $1008 \mathrm{~h}$ & $\mathrm{Ca}_{0.87} \mathrm{Na}_{0.08} \mathrm{Mg}_{0.03}\left(\mathrm{Al}_{1.82} \mathrm{Si}_{2.18}\right) \mathrm{O}_{8}$ \\
\hline
\end{tabular}

Table 6: Stoichiometry of diopside and wollastonite as function of time at $800^{\circ} \mathrm{C}$ calculated from EMPA-measurements.

\begin{tabular}{|c|c|}
\hline $\mathrm{f} 11800^{\circ} \mathrm{C}$ & Diopside \\
\hline $168 \mathrm{~h}$ & $\mathrm{Ca}_{0.98} \mathrm{~K}_{0.01} \mathrm{Mg}_{0.02}\left(\mathrm{Mg}_{0.73} \mathrm{Al}_{0.20} \mathrm{Fe}^{3+}{ }_{0.03} \mathrm{Ti}_{0.04}\right)\left(\mathrm{Al}_{0.19} \mathrm{~B}_{0.15} \mathrm{Si}_{1.66}\right) \mathrm{O}_{6}$ \\
\hline $336 \mathrm{~h}$ & $\mathrm{Ca}_{1.02}\left(\mathrm{Mg}_{0.81} \mathrm{Al}_{0.08} \mathrm{Fe}^{3+}{ }_{0.04} \mathrm{Ti}_{0.04}\right)\left(\mathrm{Al}_{0.18} \mathrm{~B}_{0.08} \mathrm{Si}_{1.74}\right) \mathrm{O}_{6}$ \\
\hline $1008 \mathrm{~h}$ & $\mathrm{Ca}_{1.02}\left(\mathrm{Mg}_{0.90} \mathrm{Al}_{0.05} \mathrm{Fe}^{3+}{ }_{0.01} \mathrm{Fe}^{2+}{ }_{0.01} \mathrm{Ti}_{0.01}\right)\left(\mathrm{Al}_{0.07} \mathrm{Si}_{1.93}\right) \mathrm{O}_{6}$ \\
\hline cf11 $800^{\circ} \mathrm{C}$ & Diopside \\
\hline $24 \mathrm{~h}$ & $\mathrm{Ca}_{0.97} \mathrm{Na}_{0.01} \mathrm{Mg}_{0.02}\left(\mathrm{Mg}_{0.74} \mathrm{Al}_{0.20} \mathrm{Fe}^{3+}{ }_{0.02} \mathrm{Ti}_{0.04}\right)\left(\mathrm{Al}_{0.12} \mathrm{~B}_{0.19} \mathrm{Si}_{1.69}\right) \mathrm{O}_{6}$ \\
\hline $168 \mathrm{~h}$ & $\mathrm{Ca}_{0.97} \mathrm{Mg}_{0.03}\left(\mathrm{Mg}_{0.72} \mathrm{Al}_{0.19} \mathrm{Fe}^{2+}{ }_{0.06} \mathrm{Ti}_{0.03}\right)\left(\mathrm{Al}_{0.06} \mathrm{~B}_{0.12} \mathrm{Si}_{1.81}\right) \mathrm{O}_{6}$ \\
\hline $336 \mathrm{~h}$ & $\mathrm{Ca}\left(\mathrm{Mg}_{0.90} \mathrm{Al}_{0.05} \mathrm{Fe}^{3+}{ }_{0.031} \mathrm{Ti}_{0.01}\right)\left(\mathrm{Al}_{0.07} \mathrm{~B}_{0.02} \mathrm{Si}_{1.91}\right) \mathrm{O}_{6}$ \\
\hline $1008 \mathrm{~h}$ & $\mathrm{Ca}_{1.01}\left(\mathrm{Mg}_{0.93} \mathrm{Al}_{0.01} \mathrm{Fe}^{3+}{ }_{0.04} \mathrm{Ti}_{0.01}\right)\left(\mathrm{Al}_{0.10} \mathrm{Si}_{1.90}\right) \mathrm{O}_{6}$ \\
\hline $\mathrm{cf} 30800^{\circ} \mathrm{C}$ & Wollastonite \\
\hline $168 \mathrm{~h}$ & $\mathrm{Ca}_{0.99} \mathrm{Mg}_{0.02}\left(\mathrm{~B}_{0.03} \mathrm{Si}_{0.95}\right) \mathrm{O}_{3}$ \\
\hline $336 \mathrm{~h}$ & $\mathrm{CaMg}_{0.02}\left(\mathrm{Al}_{0.02} \mathrm{Si}_{0.96}\right) \mathrm{O}_{3}$ \\
\hline $1008 \mathrm{~h}$ & $\mathrm{Ca}_{0.98} \mathrm{Mg}_{0.01} \mathrm{Fe}_{0.01}^{3+}\left(\mathrm{Al}_{0.03} \mathrm{Si}_{0.97}\right) \mathrm{O}_{3}$ \\
\hline $\mathrm{c} 30 \mathrm{~b} 800^{\circ} \mathrm{C}$ & Wollastonite \\
\hline $24 \mathrm{~h}$ & $\mathrm{Ca}_{0.98} \mathrm{Mg}_{0.02}\left(\mathrm{~B}_{0.04} \mathrm{Si}_{0.96}\right) \mathrm{O}_{3}$ \\
\hline $168 \mathrm{~h}$ & $\mathrm{Ca}_{0.97} \mathrm{Mg}_{0.02}\left(\mathrm{Al}_{0.02} \mathrm{~B}_{0.03} \mathrm{Si}_{0.95}\right) \mathrm{O}_{3}$ \\
\hline $336 \mathrm{~h}$ & $\mathrm{Ca}_{0.95} \mathrm{Mg}_{0.03}\left(\mathrm{Al}_{0.01} \mathrm{~B}_{0.06} \mathrm{Si}_{0.95}\right) \mathrm{O}_{3}$ \\
\hline $1008 \mathrm{~h}$ & $\mathrm{Ca}_{0.95} \mathrm{Mg}_{0.03}\left(\mathrm{Al}_{0.01} \mathrm{~B}_{0.06} \mathrm{Si}_{0.95}\right) \mathrm{O}_{3}$ \\
\hline MCAS $800^{\circ} \mathrm{C}$ & Diopside \\
\hline $24 \mathrm{~h}$ & $\left(\mathrm{Ca}_{0.98} \mathrm{Na}_{0.01} \mathrm{Mg}_{0.01}\right)\left(\mathrm{Mg}_{0.87} \mathrm{Al}_{0.07} \mathrm{Fe}_{0.05}^{3+} \mathrm{Ti}_{0.01}\right)\left(\mathrm{Al}_{0.11} \mathrm{~B}_{0.13} \mathrm{Si}_{1.76}\right) \mathrm{O}_{6}$ \\
\hline $168 \mathrm{~h}$ & $\mathrm{Ca}\left(\mathrm{Mg}_{0.88} \mathrm{Al}_{0.06} \mathrm{Fe}^{3+}{ }_{0.04} \mathrm{Ti}_{0.01}\right)\left(\mathrm{Al}_{0.11} \mathrm{~B}_{0.12} \mathrm{Si}_{1.77}\right) \mathrm{O}_{6}$ \\
\hline $336 \mathrm{~h}$ & $\mathrm{Ca}\left(\mathrm{Mg}_{0.90} \mathrm{Al}_{0.05} \mathrm{Fe}^{3+}{ }_{0.04} \mathrm{Ti}_{0.01}\right)\left(\mathrm{Al}_{0.07} \mathrm{~B}_{0.07} \mathrm{Si}_{1.86}\right) \mathrm{O}_{6}$ \\
\hline $1008 \mathrm{~h}$ & $\mathrm{Ca}\left(\mathrm{Mg}_{0.94} \mathrm{Al}_{0.01} \mathrm{Fe}_{0.03}^{3+}\right)\left(\mathrm{Al}_{0.06} \mathrm{Si}_{1.95}\right) \mathrm{O}_{6}$ \\
\hline glass $\mathrm{P} 850^{\circ} \mathrm{C}$ & Wollastonite and diopside \\
\hline $168 \mathrm{~h}$ & $\mathrm{Ca}_{0.97} \mathrm{Mg}_{0.03} \mathrm{Fe}_{0.01}\left(\mathrm{Al}_{0.01} \mathrm{Si}_{0.98}\right) \mathrm{O}_{3}$ \\
\hline $10008 \mathrm{~h}$ & $\begin{array}{l}\mathrm{Ca}_{0.98} \mathrm{Mg}_{0.02}\left(\mathrm{Al}_{0.02} \mathrm{Si}_{0.98}\right) \mathrm{O}_{3} \\
\mathrm{Ca}_{0.97} \mathrm{Na}_{0.03}\left(\mathrm{Ca}_{0.06} \mathrm{Mg}_{0.84} \mathrm{Al}_{0.04} \mathrm{Fe}^{3+}{ }_{0.04} \mathrm{Fe}^{2+}{ }_{0.02} \mathrm{Ti}_{0.02}\right)\left(\mathrm{Al}_{0.09} \mathrm{Si}_{1.91}\right) \mathrm{O}_{6}\end{array}$ \\
\hline
\end{tabular}

This article is protected by copyright. All rights reserved. 

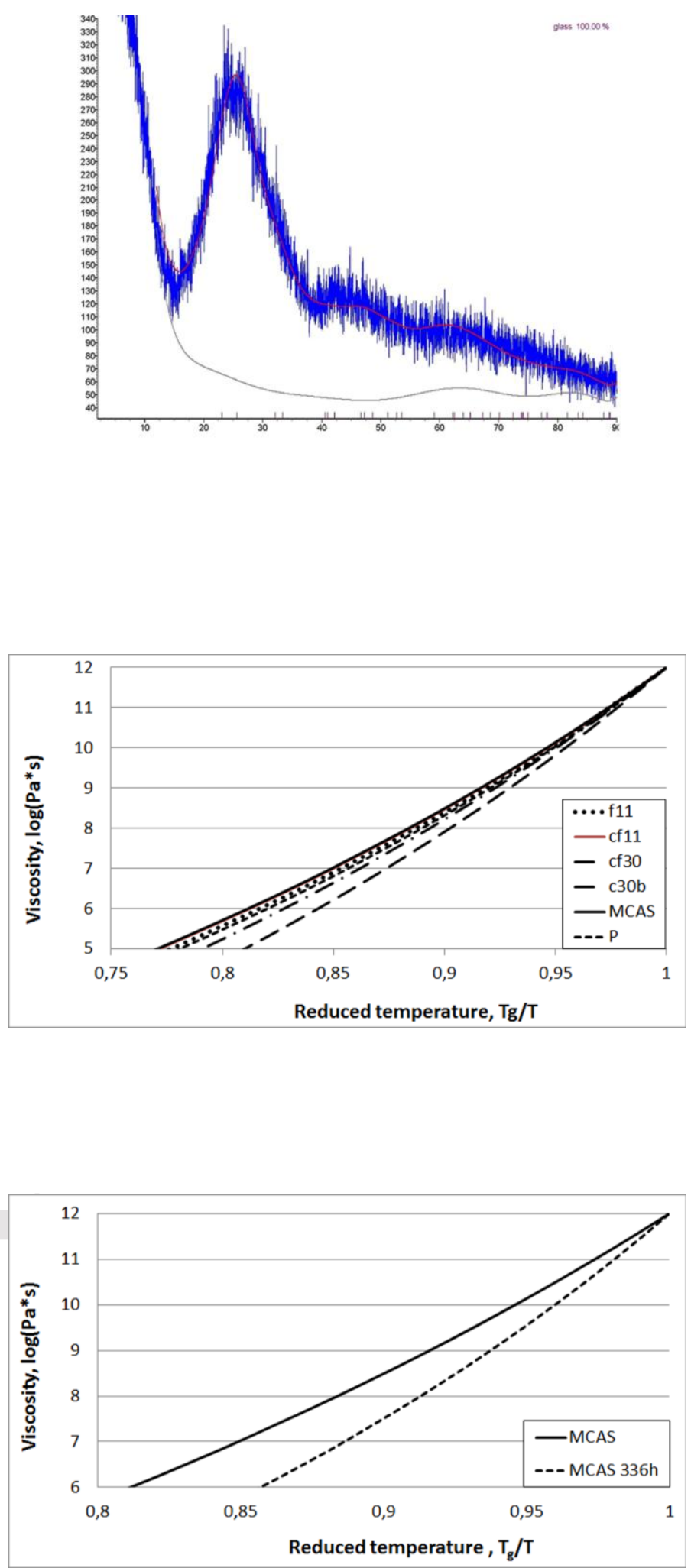

This article is protected by copyright. All rights reserved. 

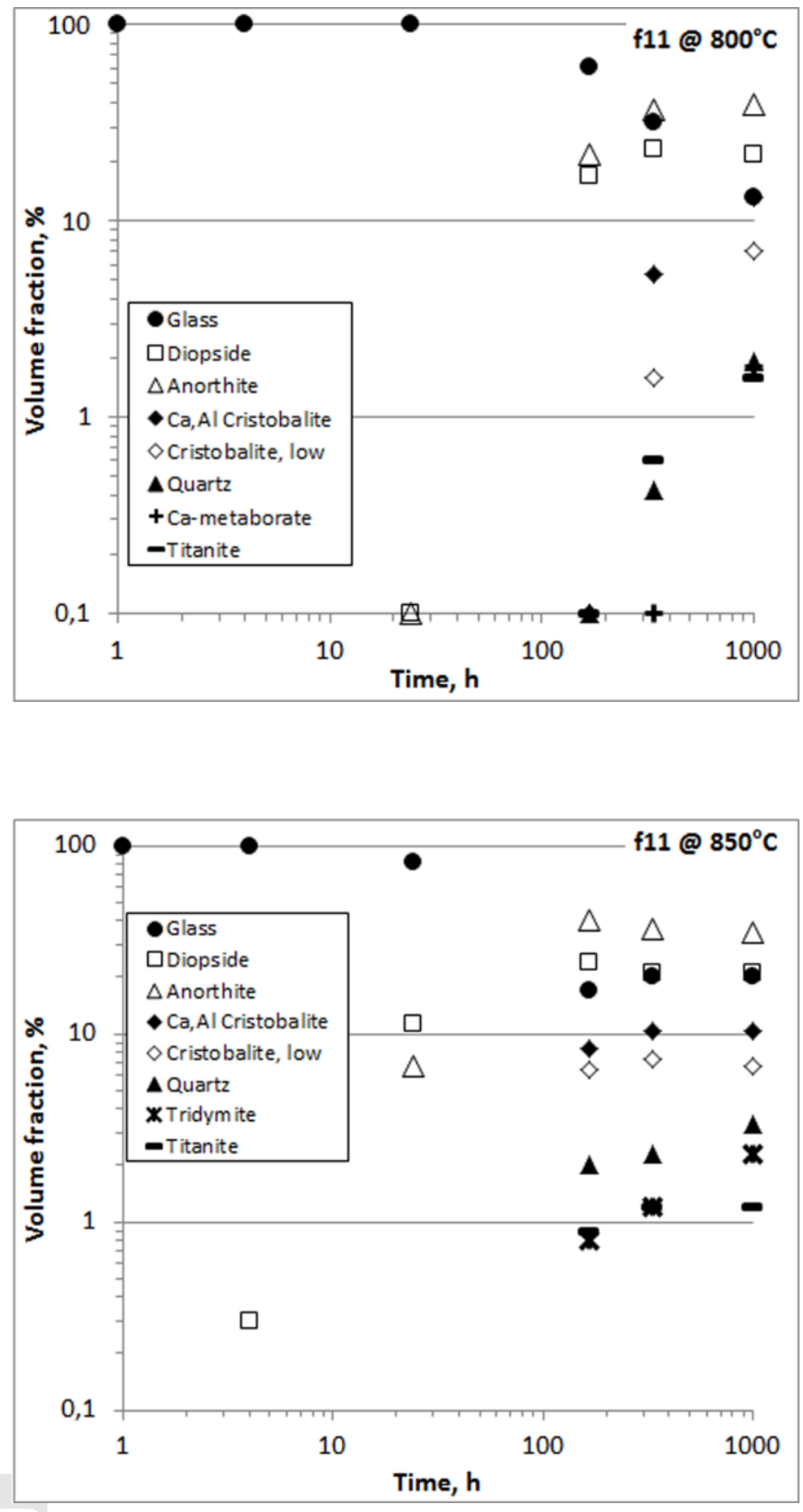

This article is protected by copyright. All rights reserved. 

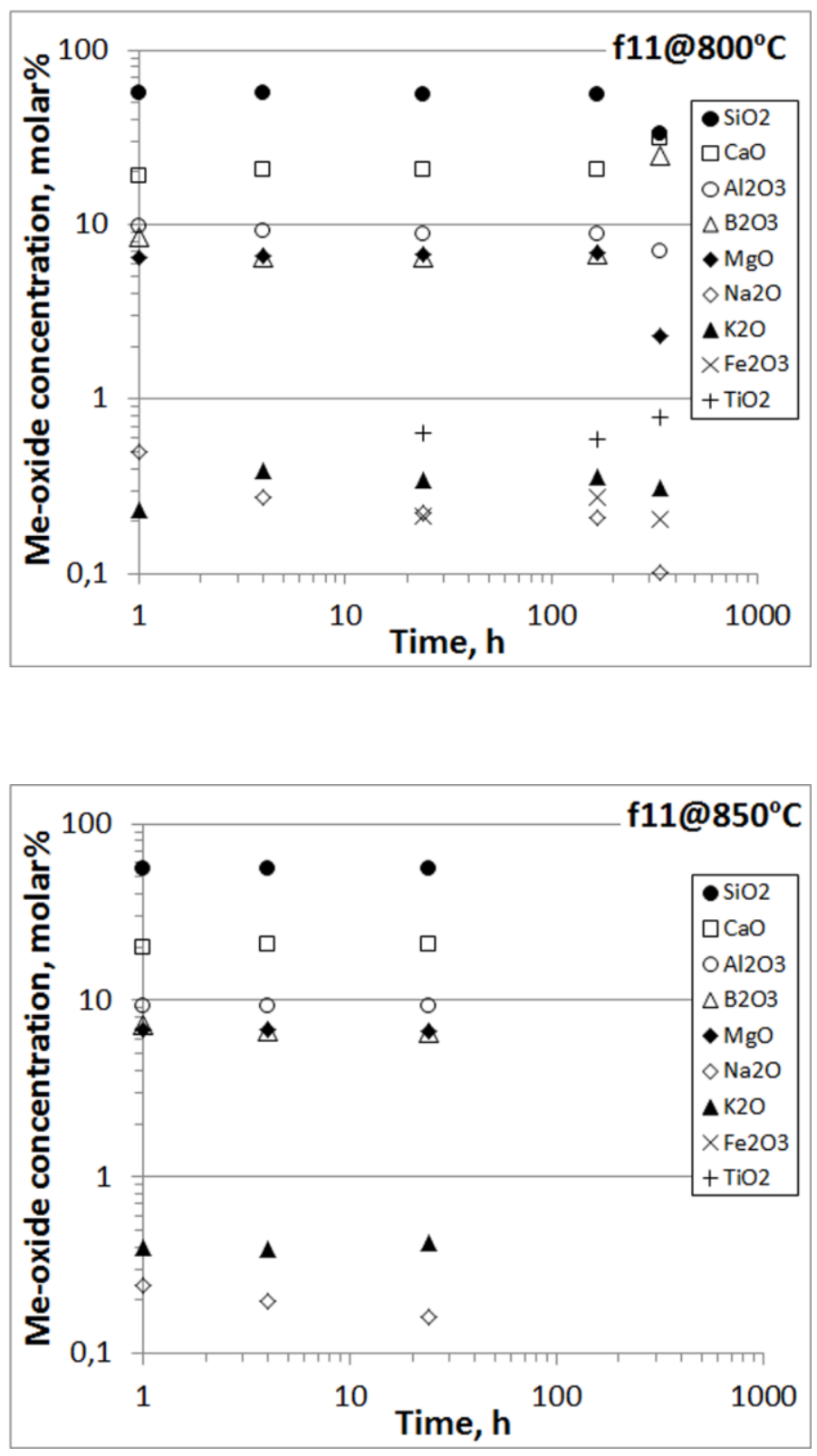

This article is protected by copyright. All rights reserved. 

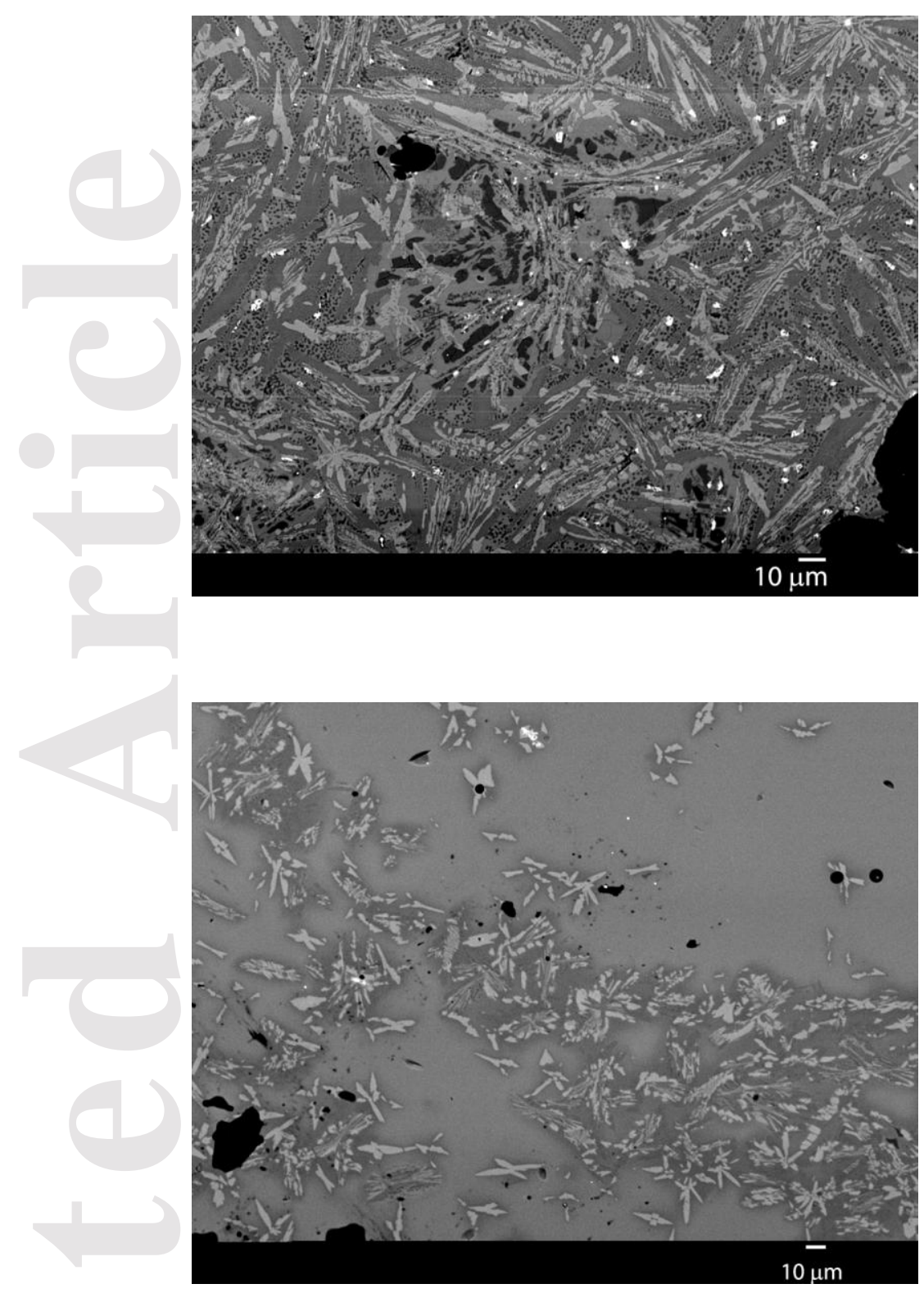

This article is protected by copyright. All rights reserved. 

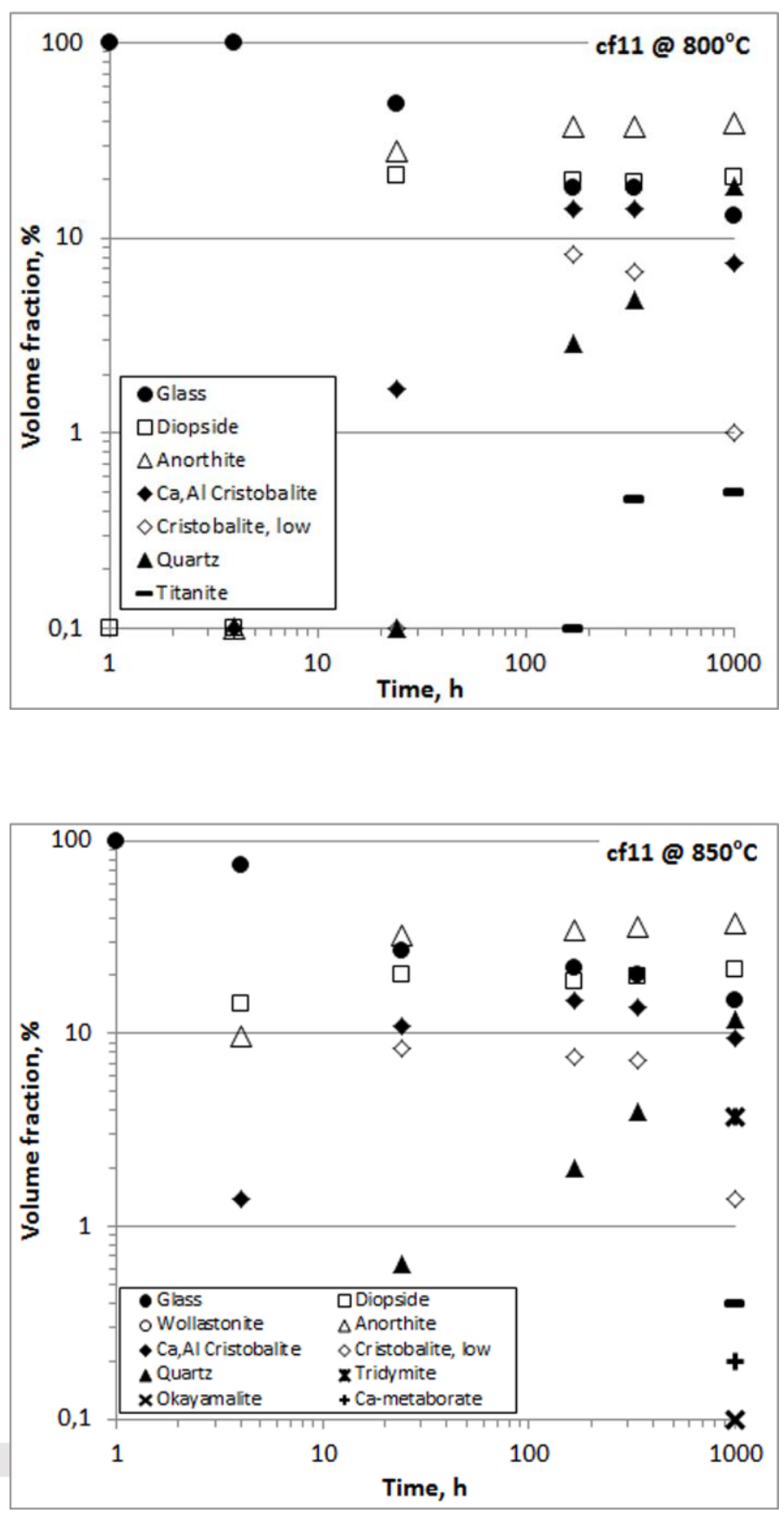

This article is protected by copyright. All rights reserved. 

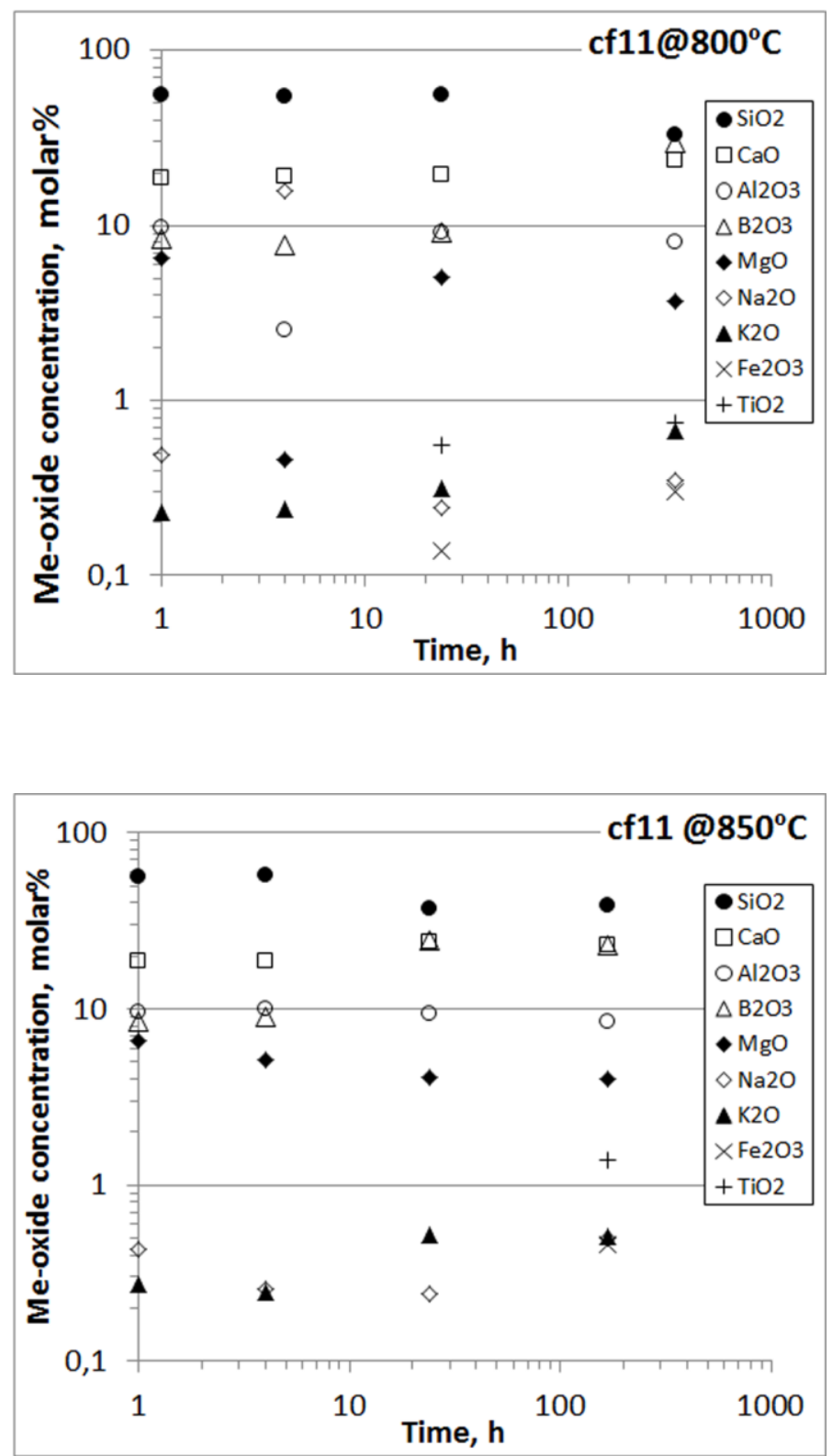

This article is protected by copyright. All rights reserved. 

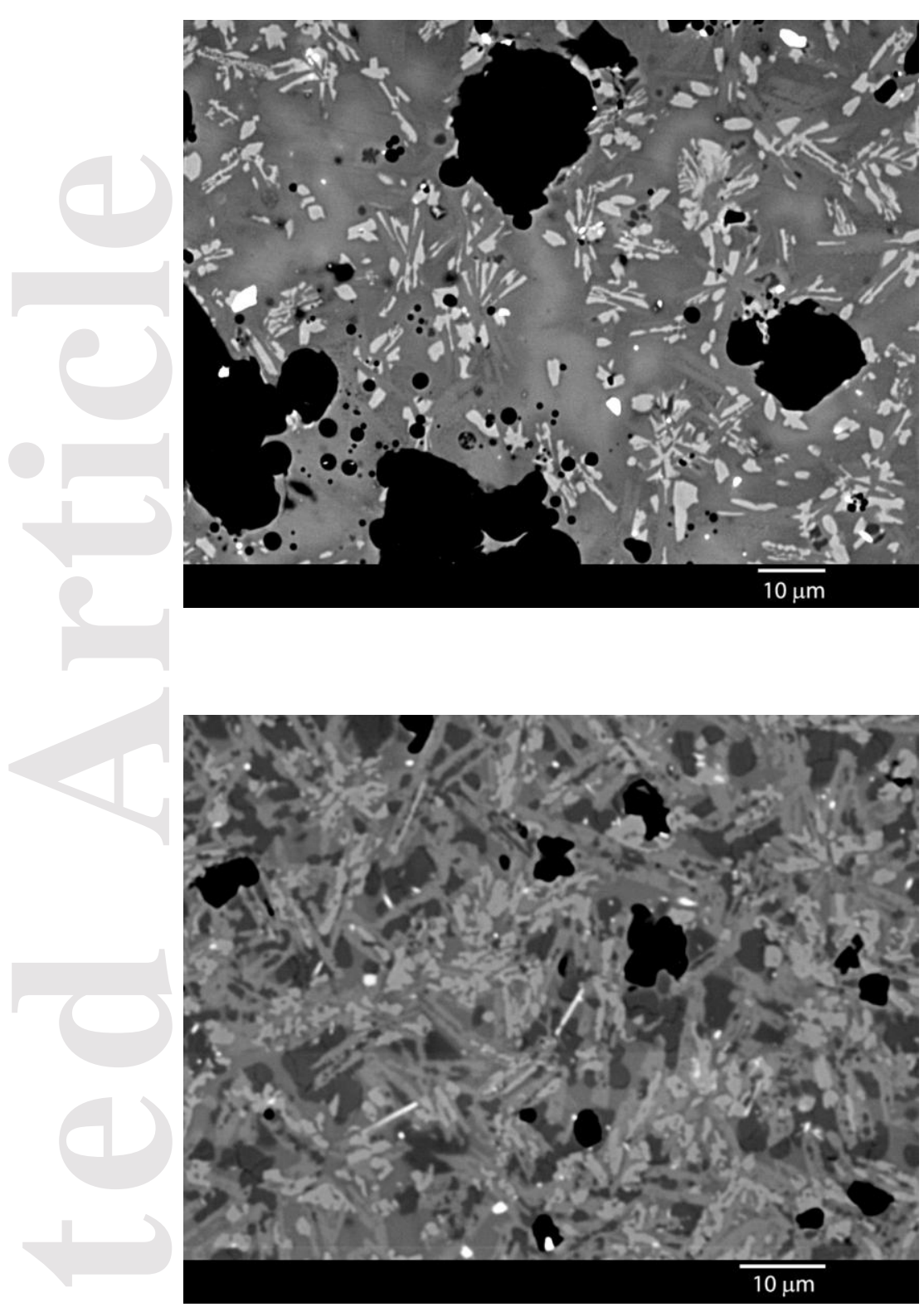

This article is protected by copyright. All rights reserved. 

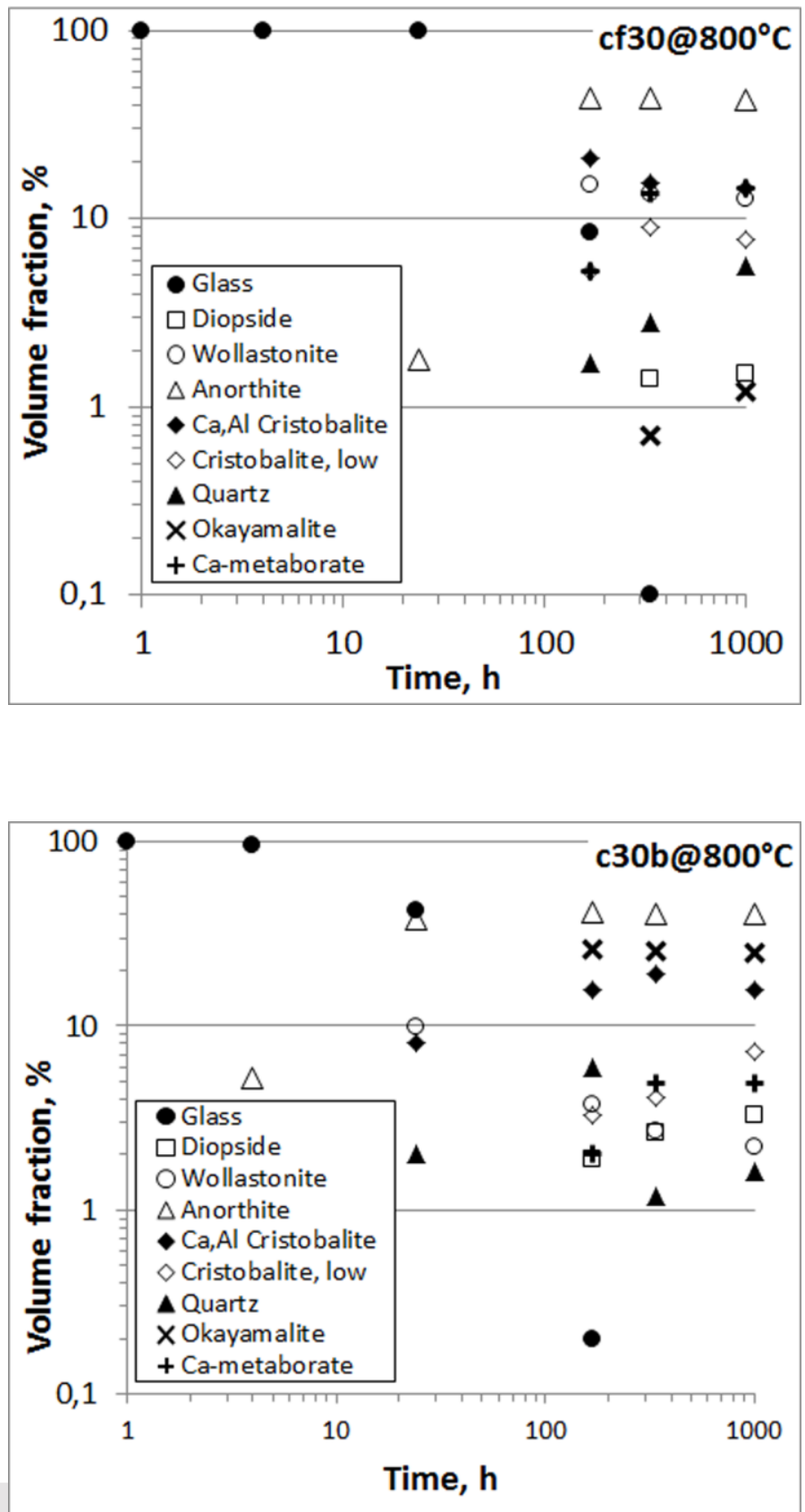

This article is protected by copyright. All rights reserved. 

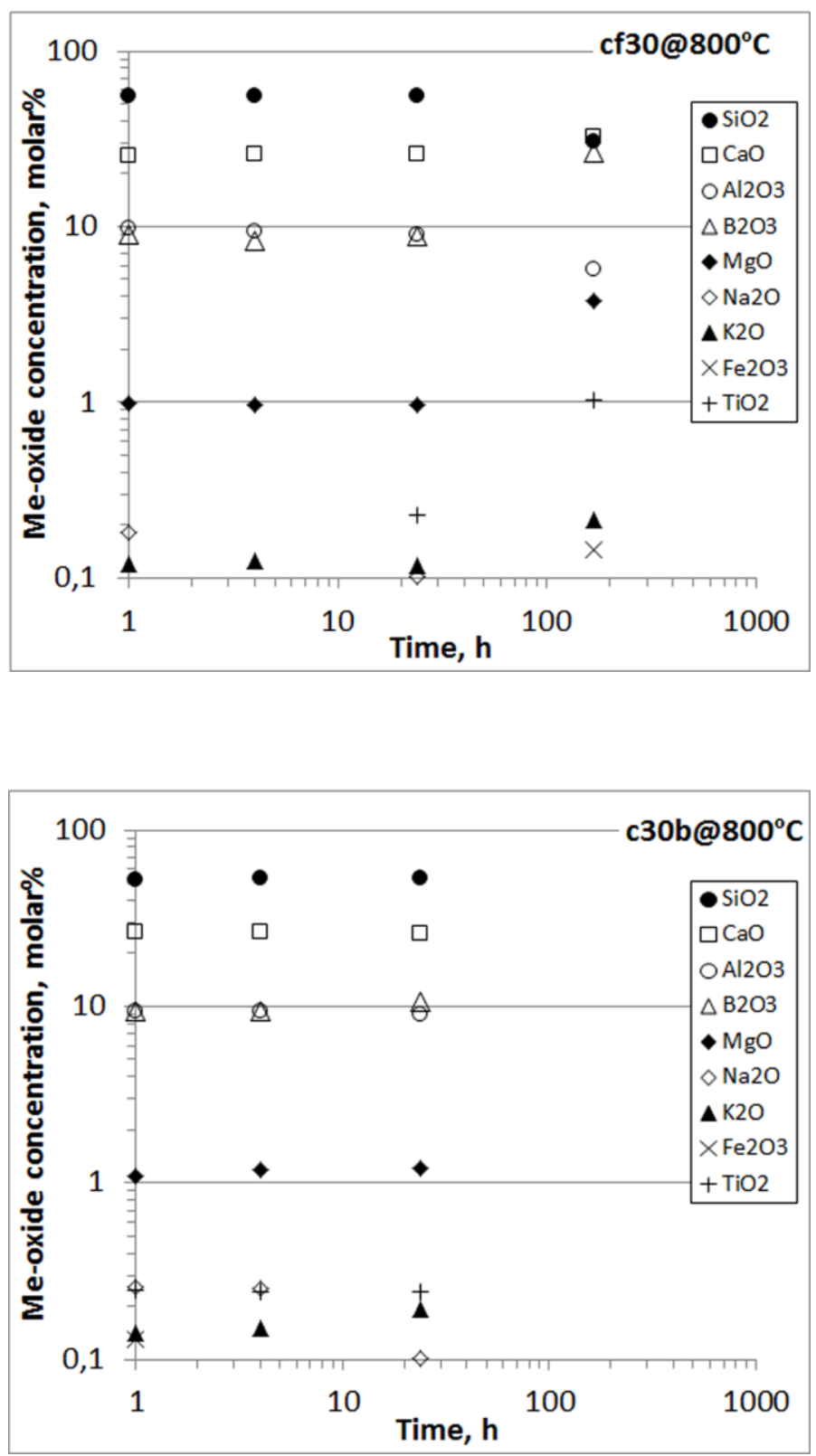

This article is protected by copyright. All rights reserved. 

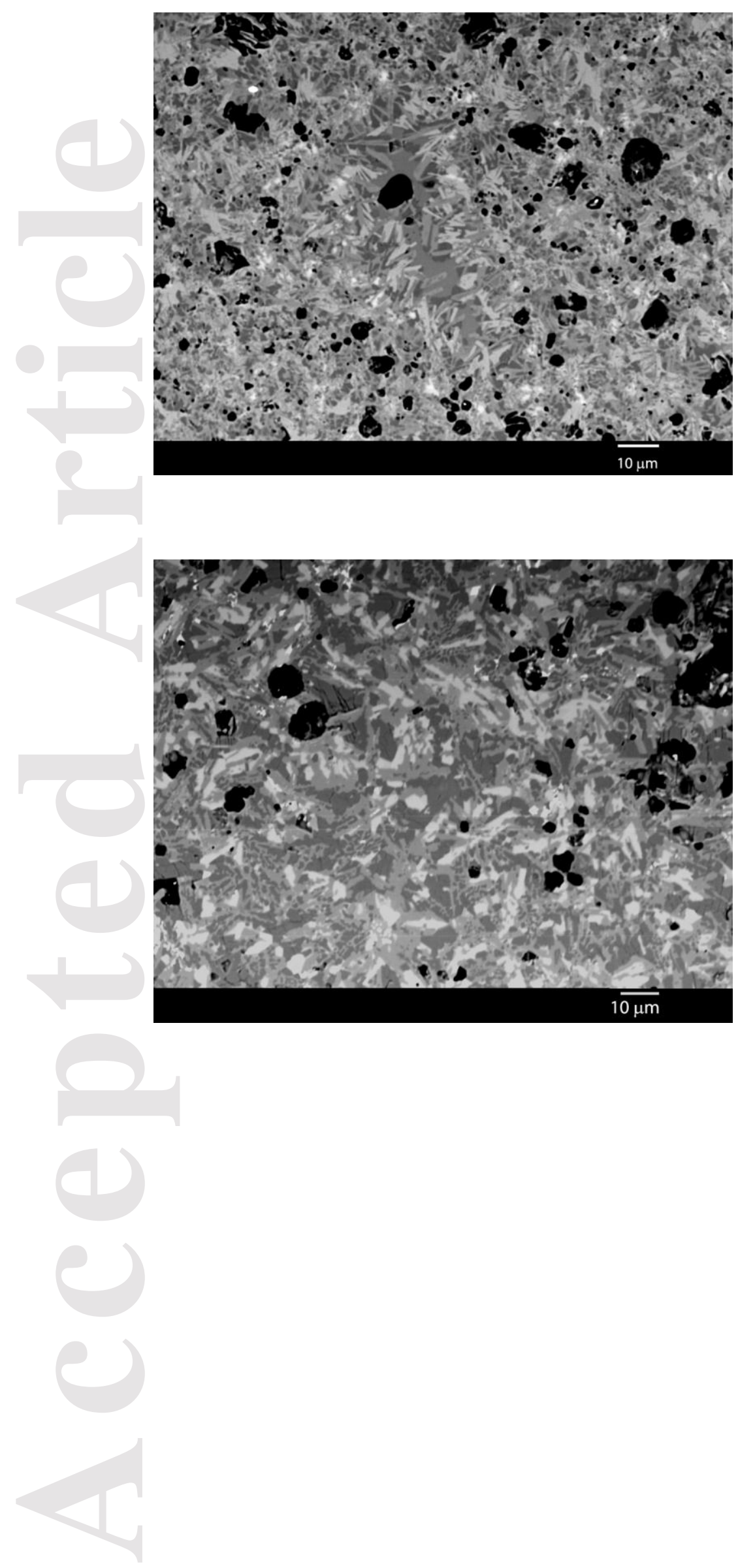

This article is protected by copyright. All rights reserved. 

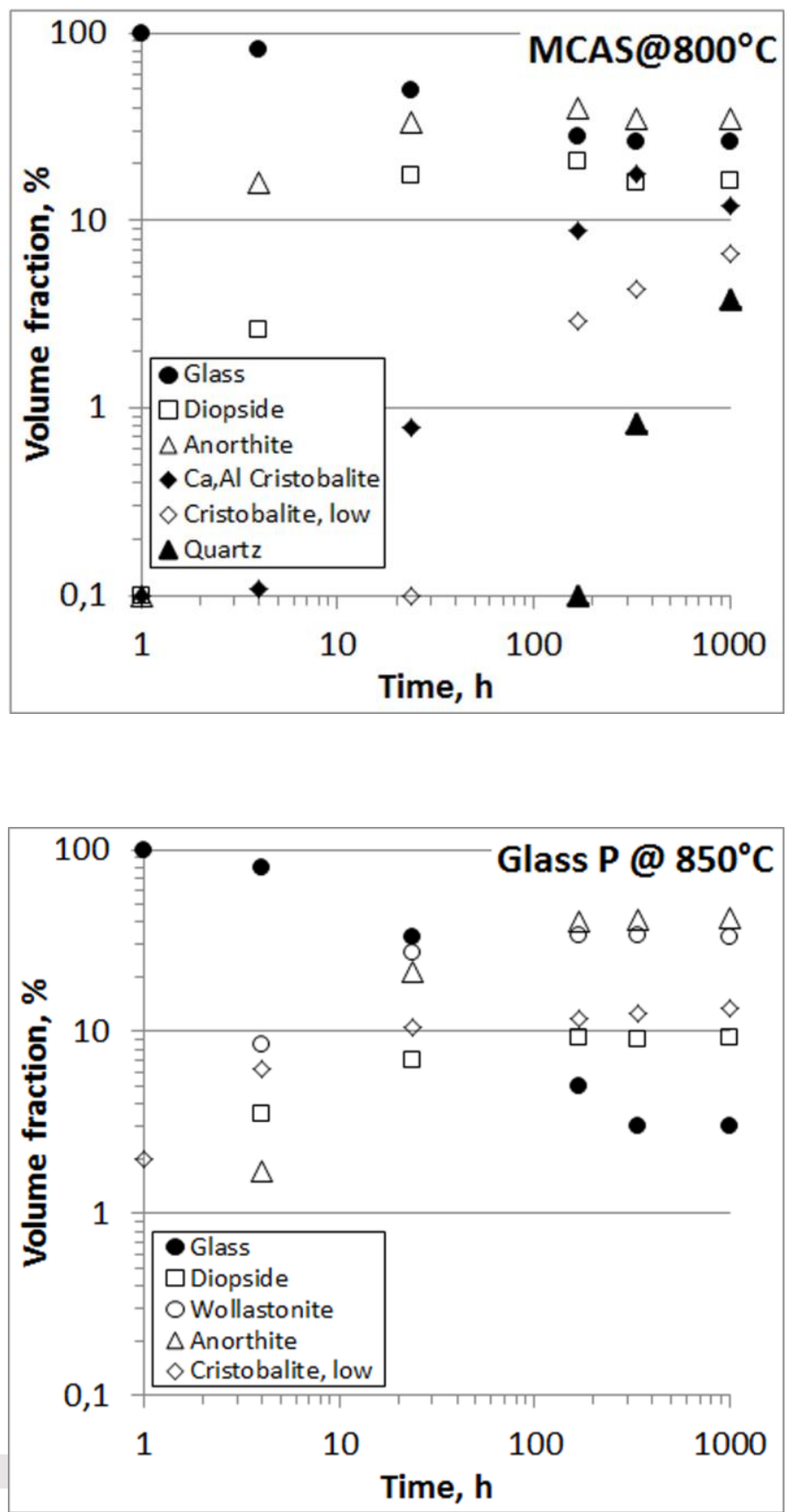

This article is protected by copyright. All rights reserved. 

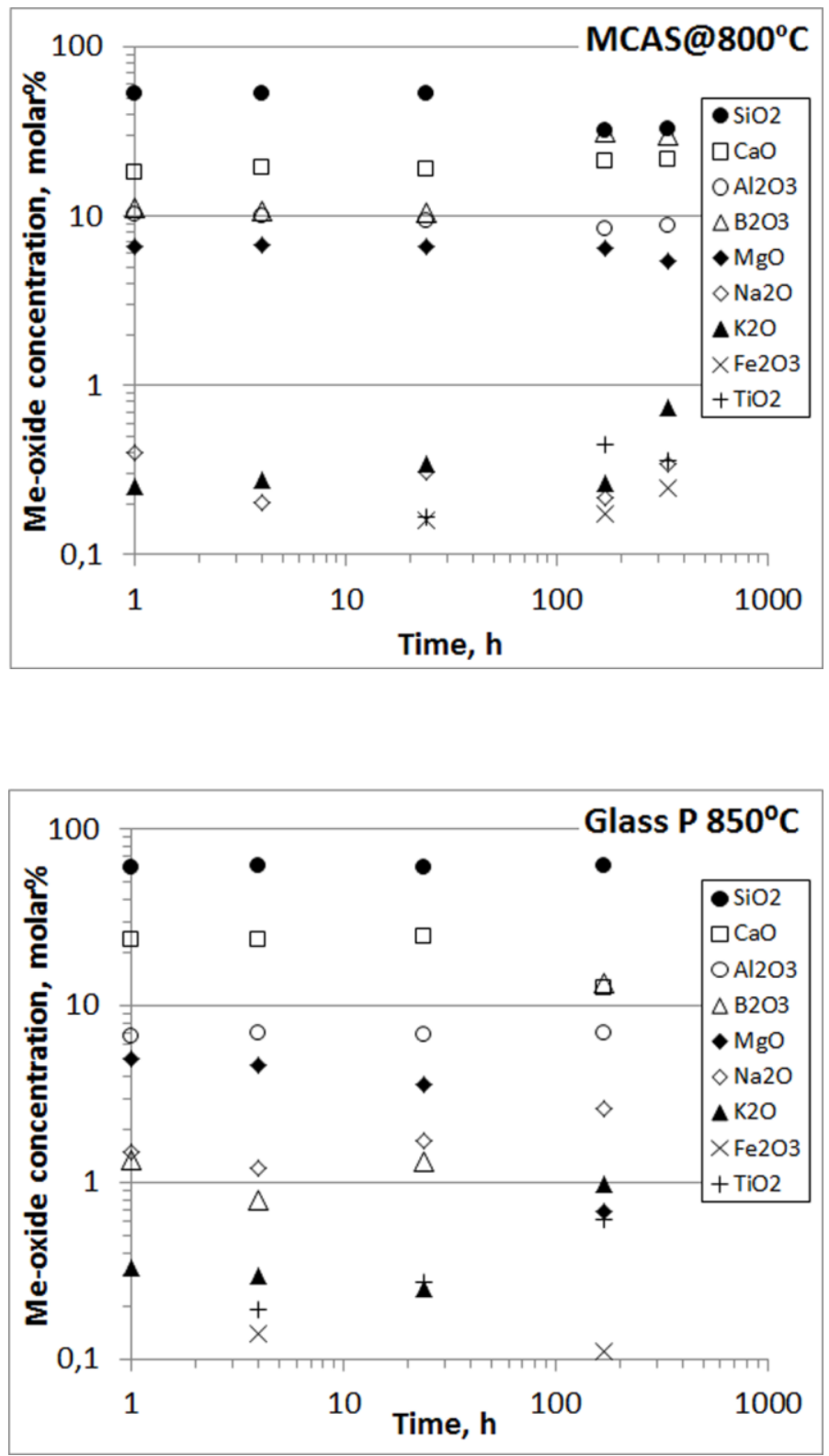

This article is protected by copyright. All rights reserved. 

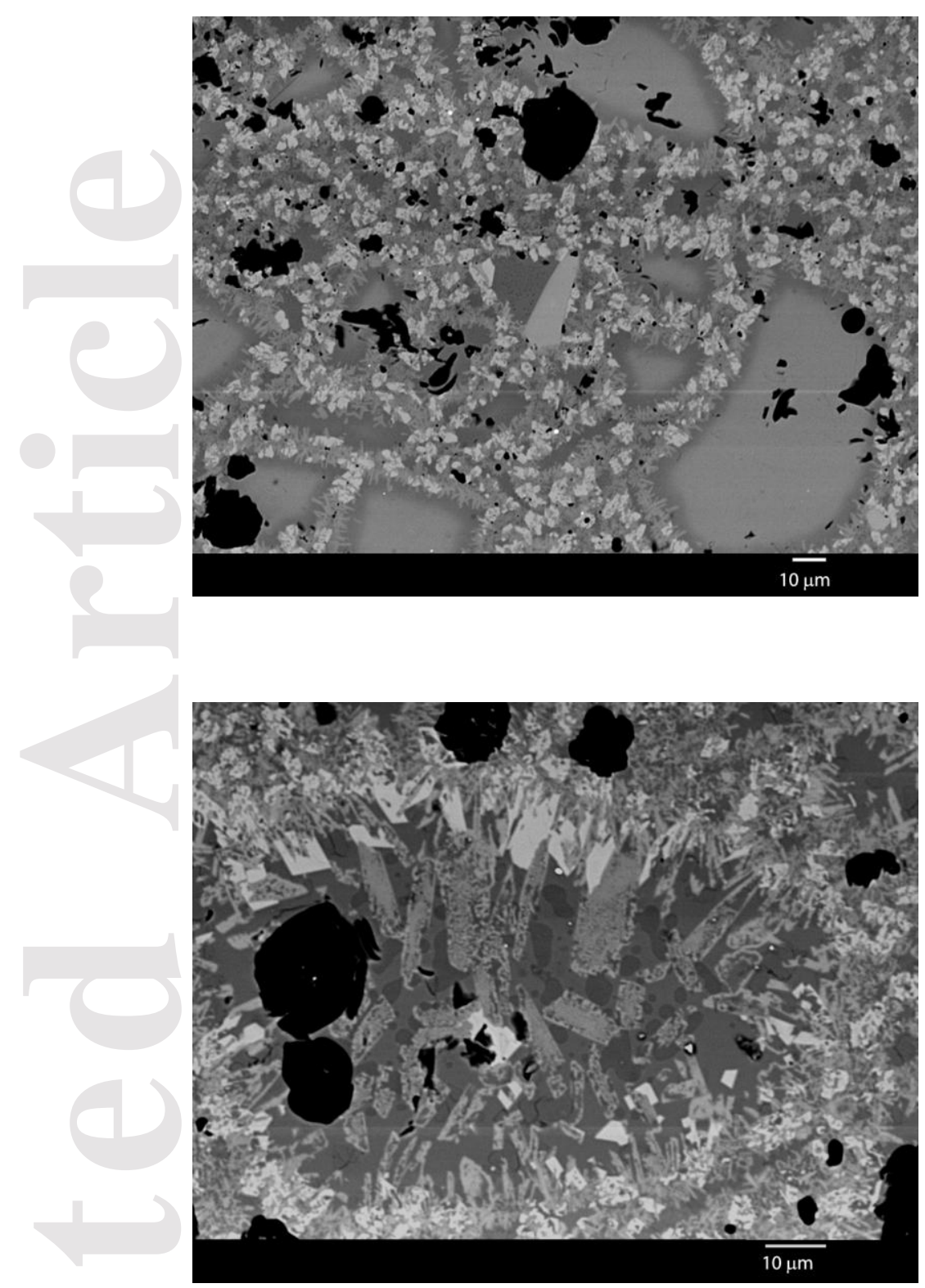

This article is protected by copyright. All rights reserved. 

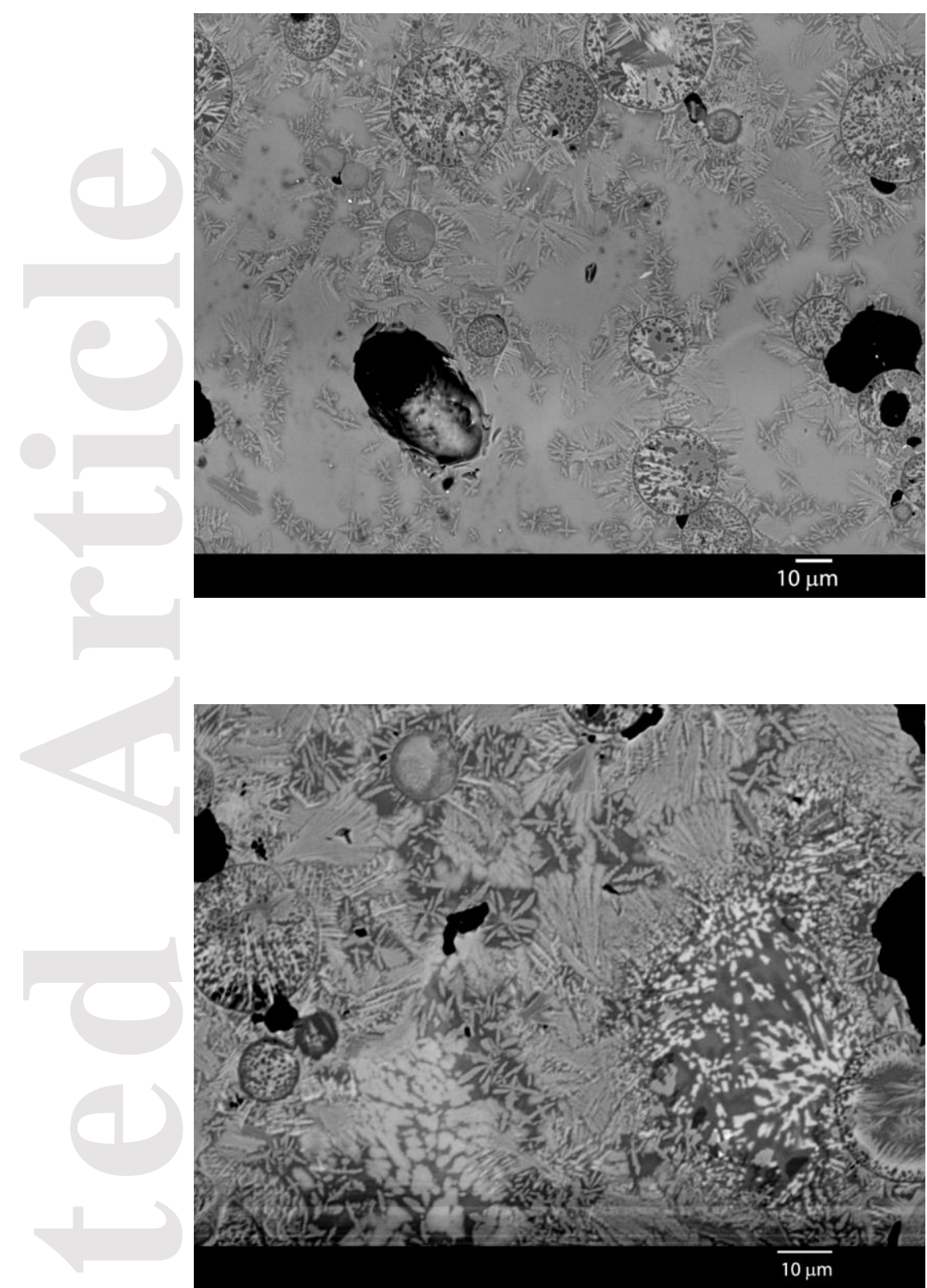

This article is protected by copyright. All rights reserved. 